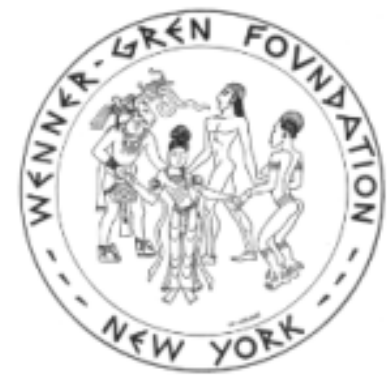

Engaged Anthropology: Diversity and Dilemmas: An Introduction to Supplement 2 Author(s): Setha M. Low and Sally Engle Merry

Source: Current Anthropology, Vol. 51, No. S2, Engaged Anthropology: Diversity and Dilemmas (October 2010), pp. S203-S226

Published by: The University of Chicago Press on behalf of Wenner-Gren Foundation for Anthropological Research

Stable URL: https://www.jstor.org/stable/10.1086/653837

JSTOR is a not-for-profit service that helps scholars, researchers, and students discover, use, and build upon a wide range of content in a trusted digital archive. We use information technology and tools to increase productivity and facilitate new forms of scholarship. For more information about JSTOR, please contact support@jstor.org.

Your use of the JSTOR archive indicates your acceptance of the Terms \& Conditions of Use, available at https://about.jstor.org/terms

The University of Chicago Press and Wenner-Gren Foundation for Anthropological Research are collaborating with JSTOR to digitize, preserve and extend access to Current Anthropology 


\title{
Engaged Anthropology: Diversity and Dilemmas
}

\author{
An Introduction to Supplement 2
}

\author{
by Setha M. Low and Sally Engle Merry
}

\begin{abstract}
As a discipline, anthropology has increased its public visibility in recent years with its growing focus on engagement. Although the call for engagement has elicited responses in all subfields and around the world, this special issue focuses on engaged anthropology and the dilemmas it raises in U.S. cultural and practicing anthropology. Within this field, the authors distinguish a number of forms of engagement: (1) sharing and support, (2) teaching and public education, (3) social critique, (4) collaboration, (5) advocacy, and (6) activism. They show that engagement takes place during fieldwork; through applied practice; in institutions such as Cultural Survival, the Institute for Community Research, and the Hispanic Health Council; and as individual activists work in the context of war, terrorism, environmental injustice, human rights, and violence. A close examination of the history of engaged anthropology in the United States also reveals an enduring set of dilemmas, many of which persist in contemporary anthropological practice. These dilemmas were raised by the anthropologists who attended the Wenner-Gren workshop titled "The Anthropologist as Social Critic: Working toward a More Engaged Anthropology," January 22-25, 2008. Their papers, many of which are included in this collection, highlight both the expansion and growth of engaged anthropology and the problems its practitioners face. To introduce this collection of articles, we discuss forms of engaged anthropology, its history, and its ongoing dilemmas.
\end{abstract}

The importance of developing an engaged anthropology that addresses public issues (Lamphere 2004; Rappaport 1993) has been the subject of numerous articles and books written in an effort to move engagement closer to the center of the discipline (Bennett 1966; Checker 2009; Eriksen 2006; Forman 1993; Hale 2006; Lamphere 2004; Patterson 2001; Rappaport 1993; Rylko-Bauer, Singer, and van Willigen 2006; Sanford and Angel-Ajani 2006; Sanjek 2004; Schensul and Schensul 1978; Smith 1999). Some argue that anthropology has been engaged from its inception, because early anthropological knowledge was developed to solve human problems as well as those of colonial administration (Bennett 1996; RylkoBauer, Singer, and van Willigen 2006). Others focus on engagement as a politically conscious critical perspective that flourished from the 1930s through the 1970s and focused on social inequality and political economic critique (Berreman

Setha M. Low is Professor of Environmental Psychology, Geography, Anthropology, and Women's Studies at the Graduate Center of the City University of New York (365 Fifth Avenue, New York, New York 10016, U.S.A. [slow@gc.cuny.edu]). Sally Engle Merry is Professor of Anthropology at New York University (25 Waverly Place, New York, New York 10003, U.S.A.).
1968; Patterson 2001; Roseberry 2002; Silverman 2007). The call for engagement has enlisted anthropologists as varied as those who argue that anthropology requires a rethinking of its methods and modes of writing to create a postcolonial relationship to its subject to those committed to finding a nonimperialist political stance to those working to formulate a new way to work collaboratively rather than hierarchically with communities. All of these forms of engagement contribute to a rich panorama of anthropological work in the public sphere.

In this article, we endeavor to provide an overview of the scope of engaged anthropology, including its major approaches and its historical development. Given the rapid emergence of engaged anthropology in the last two decades as well as the long-standing interest in such work in anthropology's history, it is impossible to do justice to the entire field. To name any scholars or practices risks leaving out others doing equally important work. However, we think it is valuable to try to trace where engaged anthropology has been and where it is now. Even though we used as wide a net as possible, our reach is inevitably limited. Others would organize and sort the field differently than we did. This is not the last word on engaged anthropology, but it aspires to open 
up the discussion, to show its breadth and variety. We deal only with social and cultural anthropology and to some extent practicing anthropology. There are significant forms of engagement in biological anthropology, such as the work of forensic anthropology; work in archeology around many issues, including repatriation; and linguistic anthropology, such as efforts to deal with the disappearance of languages. These issues are beyond the scope of this article and the collection of essays that follow. While the articles in this collection make some effort to deal with distinct national traditions, there are many more than those we were able to include. We seek to organize and systematize engaged anthropology primarily as a way to bring it, in as many of its forms and activities as possible and with its ambiguities and challenges, into greater visibility.

American anthropology's long tradition of speaking about crucial issues in contemporary society-exemplified by Margaret Mead, Ruth Benedict, and Franz Boas-is still reflected in the work anthropologists do. Now they work in fields of critical importance to contemporary public debate, from the nature of scientific knowledge and communication to the way global economic and political forces are decimating the life of forest dwellers and villagers. Anthropologists "study up," study globally, and study major institutions such as law, medicine, urban planning, and education. In these fields, the special perspective of anthropology-its focus on the microsocial situation framed by macroeconomic and political forces; its examination of the way social situations are made meaningful through discourse, symbols, and language; and its analysis of the small site's embeddedness in larger structures of poweris its unique contribution. In comparison with the growing tendency to understand behavior in broad, comparative, and statistical terms, anthropology insists on the importance of context, history, and particularity. Personally, the reason we are interested in engaged anthropology is that we are committed to an anthropological practice that respects the dignity and rights of all humans and has a beneficent effect on the promotion of social justice.

As a discipline, anthropology has pursued many paths toward public engagement on social issues. These avenues include (1) locating anthropology at the center of the public policy-making process, (2) connecting the academic part of the discipline with the wider world of social problems, (3) bringing anthropological knowledge to the media's attention, (4) becoming activists concerned with witnessing violence and social change, (5) sharing knowledge production and power with community members, (6) providing empirical approaches to social assessment and ethical practice, and (7) linking anthropological theory and practice to create new solutions. These are all important initiatives and contribute to the field's public presence. Melissa Checker's (2009) recent article offers a succinct review of the global problems that anthropologists are addressing in the areas of (1) war and peace; (2) climate change; (3) natural, industrial, and development-induced disaster recovery; (4) human rights; (5) health disparities; and (6) racial understanding, politics, and equity in the United States. She argues that the discipline is on the threshold of a new era in which anthropological expertise, activism, theory, and knowledge is being disseminated widely and freely through new technologies as well as through news media, journal publications, and institution-sponsored reports. The authors are indebted to her for providing this overview of anthropological engagement and note that its publication in American Anthropologist indicates engaged anthropology's coming of age.

We focus on the considerable progress that has been made in bringing engaged anthropology to public awareness as a discipline within U.S. cultural and practicing anthropology. It is clear that the call for engagement has been addressed in all subfields and within a global context, but these areas are beyond the scope of this article. Within this more circumscribed sphere, we argue that there are a number of forms of engagement: (1) sharing and support, (2) teaching and public education, (3) social critique, (4) collaboration, (5) advocacy, and (6) activism. This engagement takes place during fieldwork; through applied practice in institutions such as Cultural Survival, the Institute for Community Research, and the Hispanic Health Council; and as individual activists work in the context of war, terrorism, environmental injustice, violence, and human rights (Hale 2006; Kirsch 2002; Sanford and Angel-Ajani 2006; Scheper-Hughes 1995; Speed 2006).

A close examination of the history of engaged anthropology in the United States, however, also reveals an enduring set of dilemmas, many of which persist in contemporary work. After exploring the history of engaged anthropology and the current state of practice, we discuss some of the enduring challenges it poses. These dilemmas were raised by the anthropologists who attended the Wenner-Gren workshop "The Anthropologist as Social Critic: Working toward a More Engaged Anthropology," January 22-25, 2008. Their papers, many of which are included in this collection, highlight both the expansion and growth of engaged anthropology and the problems facing its practitioners. Some of the articles consider the position of anthropology in other countries to shed light on the distinctive situation of anthropology in the United States. As an introduction to this collection of articles, we discuss the forms of engaged anthropology outlined above, the history of engaged anthropology's development, and the dilemmas engaged anthropology continues to pose for anthropology. As we trace out the dilemmas and efforts to overcome them, we provide ideas for how the discipline should move forward in its work of engagement. By way of conclusion, a number of remaining barriers to engaged practice are identified and briefly discussed.

\section{The History of Engaged Anthropology in the United States}

A critical and engaged anthropology has always existed in the United States, even since the earliest professional studies dur- 
ing Reconstruction (Burawoy 2005; Patterson 2001; Textor 2005). In 1870, the first director of the Bureau of Ethnology and the Geological Survey, John W. Powell, testified before Congress about the genocide of native peoples following the building of the railroad and westward expansion (Patterson 2001; see also Vincent 1994). Before World War II there were numerous anthropologists working in the United States exposing economic problems, class divisions, and the effect of racism and inequality on American institutions and organizations (Silverman 2007).

North American anthropology in the 1920s and 1930s was still under the influence of Franz Boas. Anthropologists worked to record the cultures of native societies, especially those of Native Americans, but also did village studies in Latin America and Asia under scholars such as Robert Redfield (Silverman 2007). Boas helped to lay the groundwork linking anthropology and public life, including a critique of racism. Early studies on race relations included those of Melville Herskovits (1928) and such notable activist anthropologists as Zora Neale Hurston (Pierpont 2004; Silverman 2007). Boas also became a driving force against fascism before the war, joined by Ruth Benedict, Gene Weltfish, and Ashley Montagu (Patterson 2001; Susser 2010).

In the 1930s, engaged research was sponsored by the Depression era Works Project Administration (WPA), which employed anthropologists in several of its interdisciplinary programs. This organization supported such initiatives as the urban research and publication of Black Metropolis, socioeconomic surveys of the Southwest for the Soil Conservation Services, and rural sociological studies for the Bureau of Agricultural Economics (BAE; Silverman 2007). BAE-sponsored studies included Walter Goldschmidt's critical project on agribusiness, the Rural Life Studies, and surveys of rural areas in Bell County, Texas, by John Bennett and Oscar Lewis. Anthropologists working with Native Americans criticized the effect of trade, technology, property law, and governmental policies, showing how they put these societies in crisis (Silverman 2007). Silverman (2007) asks what happened to this materialist and critical anthropology of the 1930s. She attributes its demise to the marginality of its practitioners, most of whom did not have academic positions, and the impact of World War II, which short-circuited these activities in favor of the war effort.

Nevertheless, during this period and far beyond, Margaret Mead was a pioneer of engaged anthropology. She was active as a writer and public speaker on all facets of people living in the contemporary world (Lutkehaus 2008; Mead 1942). She tackled pragmatic problems such as housing, urban development, race, and pollution, and she collaborated with a broad range of professionals and academics. But her celebrity and success in translating anthropological insights from nonWestern cultures to critiques of American society were not necessarily received positively within the academy. In more recent years, her efforts were scrutinized for their scientific merit. Analyses of social change by Max Gluckman, A. L.
Epstein, and Victor Turner from the Manchester School in the United Kingdom, as well as Jaap Van Velsen and Godfrey Wilson, also contributed to the history of U.S. engaged anthropology, a point discussed in greater depth by Ida Susser (2010).

During World War II, 95\% of anthropologists were in some way involved in the war effort, but there were aspects of this involvement, including the administration of Japanese relocation camps, that subsequently led to the vociferous 1960s outcry at this involvement (Wax 1971, 1978). Immediately following World War II and the beginning of the Cold War, U.S.-based anthropologists were enlisted for their knowledge of "traditional" societies. Large-scale funded projects financed the investigation of militarily strategic regions and nationalcharacter studies (Silverman 2007; Smith 1999; Warren 2006), while the U.S. military invested in the Human Relations Area Files and ethnographic research on Pacific islands. June Nash (2007) writes that as a fledgling anthropologist working with unionized villagers in Cantel, Guatemala, she witnessed the 1954 CIA-triggered coup of President Arbenz and endured a subsequent visit from a CIA agent on her return to Chicago. She points to Max Gluckman's (2002 [1958]) admonition about the inherent dangers in not analyzing and instead ignoring or denying the political context of fieldwork, and she queries the limits of anthropological naivete (Nash 2007:105).

Considerable concern developed about the use of anthropological knowledge in the 1950s and 1960s, especially when many anthropologists were recruited to university settings where they were offered lucrative and tenured jobs as anthropology departments expanded with Cold War funding (Chomsky 1997; Gusterson 1996, 2004; Nader 1997; S. Silverman, personal communication). Of course, not everyone was awarded tenure or an academic post. Many women and minority anthropologists continued to work in the public sector because of barriers to their full participation in the academic sector or because they were interested in activism. The marginalized nature of their social identities and activist interests decreased the visibility and importance of activism in terms of the broader, and especially academic, face of the discipline.

During the post-World War II period and the shift to university employment for many anthropologists, the ethical problems of the use of research data by the military came under attack. During the Vietnam War, research conducted on the hill tribes of northern Thailand sponsored by the U.S. Department of Defense became the centerpiece of criticism against the military use of anthropological knowledge (González 2004, 2009; Rylko-Bauer, Singer, and van Willigen 2006; van Willigen 2002). Sol Tax's action anthropology attempted to address these criticisms by proposing that the voluntary practice of those inside the academy and other forms of valueexplicit approaches set the stage for a different kind of engaged anthropology (Rylko-Bauer, Singer, and van Willigen 2006).

Of course, a number of anthropologists opposed activism in other spheres as well as in the military one. George Peter 
Murdock in the late 1940s wrote to J. Edgar Hoover listing those anthropologists who were thought to be Communists (Price 2004). The horrific story of the fate of anthropologists at the hands of the House Hearing on Un-American Activities and the careers that were destroyed by accusations of Communist affiliation has been recounted in great detail by Laura Nader (1997) and David Price (2004). The McCarthy years limited anthropologists" free academic inquiry through "targeting, stigmatizing, and penalizing those working for racial, gender, ethnic or economic equality" (Price 2004). The cumulative effect on engaged anthropology should not be underestimated, because, "As red-baiting witch-hunts spread, a generation of social scientists learned not to overtly think under the rubrics of Marxist critique, while many in the discipline learned to ignore anthropology's natural, and ethically required, activist roles" (Price 2004:xviii). Price concludes that by midcentury, American anthropology had lost its way and retreated from the kind of engaged practice that had gone on before.

The ethical implications of military involvement and fieldnote privacy became murky as well when in 1971 the Mead Ad Hoc Committee to Evaluate the Controversy Concerning Anthropological Activities in Thailand "wrote its report exonerating all nonmilitary anthropologists of the American Anthropological Association (AAA) from the charges that they had acted unethically" (Nader 1997:126-127) and censured Eric Wolf and Joseph Jorgensen for exposing the contents of documents concerning anthropologists doing counterinsurgency research (Price 2008). Mead's concern was with the ethical implications of revealing the documents and not the consequences of the military use of the data, while Wolf and Jorgensen, joined by many others, decried the use of anthropological materials to further military aims. The report was rejected by the membership, and trust in the AAA establishment was hurt. There are similar debates today, such as about whether anthropologists should be deployed as members of Human Terrain Systems (HTS) for pacification in the wars in Afghanistan and Iraq. The AAA and the Network of Concerned Anthropologists worry about the ethical implications of this form of anthropological work for the military. In 2007, Terence Turner presented a motion to the AAA to change its code of ethics to preclude any form of clandestine research and reinstitute the 1971 AAA Principles of Professional Responsibility, while a full report on HTS and an evaluation of its effect on the discipline was completed in October 2009, circulated at the annual meeting, and posted on the AAA Web site.

Critical engaged anthropology survived the McCarthy era in a number of academic settings. Marshall Sahlins, Stanley Diamond, Eric Wolf, Marvin Harris, Constance Sutton, Kathleen Gough, and David Aberle organized Vietnam "teach-ins." In 1963, Eleanor Leacock along with June Nash and Helen Safa fought for better working conditions for women both in the United States and Latin America, while Sutton and Leacock organized the New York Women's Anthropology Caucus in the early 1970s. These efforts morphed into the International Women's Anthropology Caucus led by Leacock and Sutton and later by Johnetta Cole and Linda Basch. The caucus affiliated with the United Nations to connect with scholars in the third world countries (Berreman 1968; Sutton 1993; C. Sutton, personal communication). Also in the 1970s and 1980s, Christine Gailey, Louise Lamphere, Richard Lee, and many others joined Leacock in her campaign (Patterson 2001; Roseberry 2002). An activist perspective founded during the civil rights movement and the Vietnam War resulted in a special issue of Current Anthropology in which Kathleen Gough (1968) analyzes imperialism, Gerald Berreman (1968) examines social responsibility in social anthropology, and Delmos Jones (1968) discusses "insider anthropology" as an African American anthropologist following in the footsteps of W. E. B. DuBois and St. Clair Drake (Susser 2010). Feminist anthropology also flourished during this period, urging more inclusive methodologies, active engagement with the individuals and communities studied, and more egalitarian research relationships (Huggins and Glebbeek 2009; Susser 2010).

According to William Roseberry (2002), three critiques of anthropological practice emerged following World War II. The first was in the late 1940s and early 1950s, and it questioned "primitive isolates" as the traditional object of study and expanded the field to include complex societies and new social groups (Roseberry 2002:59). The second was from the late 1960 s and the early 1970s and grew out of the past anthropological collusion with colonial powers and the failure of the discipline to recognize women and other forms of race, class, and ethnic discrimination. It was marked by the publication of Eric Wolfs (1969) Peasant Wars of the Twentieth Century and Marvin Harris's (1964) Patterns of Race in the Americas. This critique was grounded in political economy, historical materialism, and the empirical and realist traditions of Marxist theory. Engaged scholars published Reinventing Anthropology (Hymes 1969) that proposed an anti-imperialist stance (Berreman 1968; Caulfield 1969). It also urged "studying up" to understand the culture of power and not just the culture of the dominated (Nader 1972) and moving from the academic world to working for communities or movements, even doing direct action as a member (Hymes 1969:56).

The third critique began in the mid-1980s with the publication of George Marcus and Michael Fischer's (1986) Anthropology as Cultural Critique and James Clifford and George Marcus's (1986) edited volume Writing Culture, and it continued through the early 1990s. Also employing the language of critique, its focus was on examining "the formation and cultural construction of identities" (Roseberry 2002:70) and interrogating received metanarratives, especially those of the white male anthropologist. This "cultural critique" addressed issues of inequality and voice discursively_often from a Foucauldian, deconstructivist, or postcolonial/subaltern theoretical perspective-and argued for a more reflexive form of ethnographic practice that values multivocal and coconstructed knowledge and narrative. 
By the late 1970s and 1980s, engaged anthropology began incorporating these critiques by involving advocacy for and participation of studied populations and individuals (Hill 2000). Informants became collaborators, co-researchers, and colleagues rather than the subjects of study. Much of this research was based on theories of uneven development and power differentials between the core and periphery, but it also focused on the way that race, class, gender, and ethnicity structured socioeconomic inequality. The notion of "devolution of power to communities" at Hacienda Vicos in Peru was grounded in the idea that successful development could occur only if the structural inequalities of peasant life could be changed (Doughty 1987). Jean Schensul and Stephen Schensul's "collaborative research model" (Schensul and Schensul 1978, 1992) and Dennis Weidman's "cultural brokerage" (Weidman 1976) were new approaches to engaged research developed during this period.

By 1993, Shepard Forman's Diagnosing America: Anthropology and Public Engagement issued an "outspoken call for a committed and engaged anthropology" (1993:3) as part of an AAA panel "Disorder of Industrial Societies." The edited volume concludes with a "Statement to the Profession" that speaks to many of the issues addressed in this article, arguing for "an anthropology that includes prominently among its missions empirically grounded social criticism on the one hand and theoretically guided participation in public policy processes on the other" (Forman 1993:298). The statement identifies five aspects of engagement: (1) anthropology as a source of social criticism, (2) community engagement, (3) policy voices, (4) classroom engagement, and (5) reengaging anthropology defined as continuous self-criticism from within the discipline. Its recommendations include many steps that have been taken by the AAA, such as the creation of a commission on diversity (the current Commission on Race and Racism), a commission on the presence of women in academic anthropology (the standing Committee on the Status of Women in Anthropology), support for minority colleges (the standing Committee on Minority Affairs), and a reexamination of tenure and promotion criteria, an issue that is also identified as a barrier to engaged work in the conclusion of this article and is currently being addressed by the Committee on Public, Applied, and Public Interest Anthropology (COPAPIA).

Even with this milestone published in the early 1990s and AAA's efforts to move the discipline toward engagement, there remained considerable silence about the kinds and degree of advocacy and activism that would be supported within the discipline and especially within the academy. During the 1990s and early 2000s, however, a growing number of anthropologists have been pushing for increased activism both within and outside the academy. Nancy Scheper-Hughes's proposal for a militant anthropology suggests that "cultural relativism, read as moral relativism, is no longer appropriate to the world in which we live and that anthropology, if it is to be worth anything at all must be ethically grounded" (1995:410). With this moral claim, she argues that anthropological writing can be a site of resistance. James Peacock's presidential lecture titled "The Future of Anthropology" introduced the idea of public anthropology and worked with other anthropologists to suggest that engaged anthropology should include transforming academia and breaking out of the stratification of anthropology itself (Basch et al. 1999; Peacock 1997). Gavin Smith's (1999) Confronting the Present: Towards a Politically Engaged Anthropology prescribes moving from political engagement to formulating anthropology as a political practice, and Stuart Kirsch (2002) offers an impassioned plea for the appropriateness of advocacy in cases of environmental injustice. Lassiter (2005) advocates writing collaborative ethnographies and has begun editing a journal, Collaborative Anthropologies (in 2009), to further this initiative, while Victoria Sanford and Asale Angel-Ajani (2006), Shannon Speed (2006), and Charles Hale (2006) claim that critical engagement can best be achieved by activist research and advocacy rather than academy-based cultural critique.

A diversity of engaged anthropologies emerged from this ferment. Some are forms of support, teaching, and communication; others are social critique-the scholarly pursuit of uncovering the bases of injustice and inequality; and some concern the collaborative approach to research by working with research subjects through collaborative and equal relationships. Some are more radical forms of engagement centered on advocacy and activism. These divisions and categories are not rigid or static, but we use them to provide a sense of the diversity of engagements practiced in the United States today.

\section{Forms of Anthropological Engagement}

One of our arguments is that anthropologists are engaged in a variety of ways, but, as indicated by the history, they do not necessarily agree about what constitutes engagement much less about the form that it should take. Our position is that there is a wide range of practices we would include under this rubric and that this breadth strengthens the discipline. We offer a preliminary typology, although it is not intended to be a set of mutually exclusive categories, because all the types of engagement are overlapping and interpenetrating. They serve, however, to describe the range of engagement and to clarify the discussion of the articles that follows.

\section{Sharing and Support}

Anthropological field research typically includes everyday practices of sharing, support, and personal interaction. Such relationships, which include friendship and even forms of kinship, can be thought of as a form of engagement. For example, John Jackson (2010) discusses the importance of sincerity rather than authenticity as the basis for an engaged ethnographic practice. Ethnographic explorations based on 
authenticity seek to establish whether a person is an authentic member or subject of a group, an approach that converts the person to an object. Sincerity, in contrast, refers to a state of inner commitment. It offers another way of rendering the real but one that is always incomplete because it is never possible to know fully about another's sincerity. Jackson advocates a mode of ethnography not driven by the desire for the authentic or the real but by humor, affect, and a concern for sincerity.

Shared commitments to visions of social justice or social change are another form of engagement in ethnographic practice. Kamran Ali describes his sympathy for poor women of Karachi dealing with their fear and the violence of the streets in their everyday lives, and he asks at what point anthropologists should intervene with universalizing discourses such as human rights or empowerment to help them cope with these stresses (Ali 2010). Most anthropologists share not only social and political commitments with the people they work with or study but also their housing, food, medicine, automobile, and other economic, material, and social resources, both at home and in the field. These everyday acts of sharing and support may not seem like "engagement" in terms of advocacy or activism, but they reflect the anthropological sense of responsibility and reciprocity that often develops into other forms of engagement. João Biehl describes his efforts not only to document the life of a poor, ill woman in a Brazilian zone of abandonment but also to help her by trying to determine the nature of her illness (Biehl 2005; see also Briggs 2004; Briggs and Mantini-Briggs 2000; Farmer 2003).

\section{Teaching and Public Education}

Instruction in classrooms, in training programs in the context of practicing anthropology, and in individual advising and mentoring constitute another form of engagement. For example, Jackson talks about teaching as a form of engagement, while Susser describes developing an ethnographic training program on AIDS in social context in Namibia and South Africa (Susser 2010). Howell's description of the role of anthropologists in public debate in Norway over issues such as indigenous rights and the absorption of immigrants suggests that teaching can also take place through the media and popular writing (Howell 2010).

Active engagement in teaching that includes involving students in research and community outreach projects is a hallmark of many anthropology programs. Many programs, especially those that have applied anthropology concentrations or specialization, have developed internships for their students in local governmental agencies and community service institutions where both the faculty and the students work for and with people within the town, city, or region on local problems and initiatives. Faculty and students interested in engagement often set up community research centers where they develop cooperative projects between university and college-based fac- ulty and students, and these outreach activities are incorporated into the curriculum as well.

Engaged teaching is also found in kindergarten through high school programs designed to offer an anthropological perspective and knowledge base to children and young adults. The AAA Committee on Anthropology and Education (CAE) focuses on promoting such projects because of their wide reach and immense public effect. Norma González (2010) discusses the importance of anthropological interventions in schools and the way that teaching incorporates insights about language and racial inequality as engaged practices with the power to transform education inequity.

Many practicing and applied anthropologists run training programs that engage the public and their clients in intense interaction over a limited period of time. Public workshops, lectures, seminars, and other forms of public programming are important components of engaged teaching. Sometimes this kind of engagement evolves out of research in the public sector, such as the work of the Public Space Research Group's 20 years of park studies for the National Park Service, the City of New York Department of Parks and Recreation, and other public agencies and institutions (Low, Taplin, and Scheld 2005). This group's research on cultural diversity and the inequality of access to adequate and appropriate park resources by gender, race, ethnicity, class, age, and ability produced a set of "lessons" that are now being used as the basis for training workshops for park managers and designers, historic preservationists, and urban planners in the United States and in Canada and Australia (Low 2002, 2004, 2006, 2008, 2010). Thus, "teaching" as an engaged activity has many forms, include classroom teaching, community outreach, training, workshops, and numerous other pedagogical and didactic forms, including serving as a public intellectual. Engaged careers in academic teaching and public education also produced a number of innovative academic leaders, such as Johnetta Cole at Spelman College and Judith Shapiro at Barnard College, who have inspired students and faculty to further engage with contemporary social issues.

\section{Social Critique}

Social critique in its broadest sense refers to anthropological work that uses its methods and theories to uncover power relations and the structures of inequality. There are many excellent examples of this kind of work in anthropology, typically drawing linkages between individual or group suffering and structural factors by examining harms in historical context and within relations of power. For example, Paul Farmer (2003) links disease with larger conditions of structural violence: the actions of institutions, states, and the unequal provision of medical services (see also Farmer 2004, 2005). João Biehl (2005) shows how everyday practices of pharmaceutical companies and medical services consign certain individuals to a zone of abandonment outside the space of ordinary life (see also Biehl 2007). Ugo Mattei and Laura 
Nader (Mattei and Nader 2008) document the extent to which the rule of law not only failed to prevent but actively contributed to the global extraction of resources by rich and powerful countries. A body of scholarship on social suffering foregrounds the pain suffered by ordinary people and the possibilities of healing through the return to the everyday (Das 2007; Das et al. 2001). Anthropologists have worked to expose the destruction of development (Ferguson 1994), the suffering of poverty and hunger (Scheper-Hughes 1992), and the ravages of environmental degradation (Tsing 2005). Some anthropologists, such as Victoria Sanford, focus on exposing the human rights abuses suffered by individuals in conflict zones (Sanford 2004).

There is a rich literature on processes of conflict and violence such as genocide (Hinton 2002a, 2002b; Hinton and Lifton 2004; Hinton and O'Neill 2009), human rights violations (Cowan, Dembour, and Wilson 2001; Goodale 2008, 2009; Tate 2007), gender violence (Merry 2008), transitional justice and the aftermath of war (Clarke 2009; Nelson 2009; Wilson 2001), and violence more generally (Scheper-Hughes and Bourgois 2004; Starn 1995). These are only a few examples of a rich and variegated set of studies that seek to excavate hidden or everyday forms of violence and abuse and explain their incidence in terms of larger structures of wealth and power. Susser (2010) offers an account of the problem of AIDS in South Africa framed by the political economy of the country and shows how the Manchester School's work on the Zambian Copperbelt developed this form of analysis in the 1930s and 1940s (see also Susser 2009).

Another form of social critique exposes the misuse of concepts within everyday discourse, particularly when these concepts lead to discriminatory behavior. There is a long history of this work as well, some of which focused on exposing the fallacies of racial thinking. Often, this means critiquing the misuse of anthropological theory and concepts such as the culture of poverty. For example, González shows how the concept of culture, including the culture of poverty, is hijacked as a way to explain poor school performance and ultimately to exclude migrants. As "culture" is used to explain achievement differences between whites and Hispanics in schools, it comes to stand in for the concept of race and obscures the critical importance of poverty and uncertain immigration status on school performance (González 2010). Similarly, the racist underpinnings of "modernization" efforts are employed to destroy low-income housing areas in Rome (Herzfeld 2010). Signe Howell describes the way the anthropological concept of culture has been used in public debates in Norway in ways that concern Norwegian anthropologists (2010). In the international sphere, the concept of culture is used to explain the persistence of practices harmful to women in developing countries. Explaining the persistence of these practices in terms of "culture" reinforces colonial ideas of backwardness while ignoring the extent to which these practices are contested by local activists and supported for political reasons by conservative elites (Merry 2006).
Some forms of social critique directly tackle the misuse of anthropological concepts and knowledge circulating in elite public spheres. Hugh Gusterson and Catherine Besteman (2005, 2010), for example, edited two collections of essays by anthropologists critiquing the statements of pundits about a variety of popular topics concerned with culture. The Network of Concerned Anthropologists takes on areas where anthropological knowledge is being used in ways that cause concern for many anthropologists, such as helping military engagements, an issue also addressed by Catherine Lutz (2001, $2002,2006,2008$ ) in her critiques of the military and the role it plays in everyday life in the United States.

\section{Collaboration}

Another dimension of engaged anthropology is a collaborative approach to research and practice. Collaborative research ranges from participation in the research site to collaborative leadership through action research. Participation in a research site is a low-key form of collaboration in which the researcher works with local organizations or social movements in carrying out their missions but does not actively lead them. This might mean doing child care during women's support groups in a domestic violence program or working as an intern in a human rights organization in order to study how it operates. Collaborative research also takes the form of shared leadership of a research project. For example, Sally Merry and Peggy Levitt developed a comparative study of the vernacularization of women's human rights by women's NGOs in India, China, Peru, and the United States by collaborating with scholars in these countries (Levitt and Merry 2009). Another example of this collaborative approach is the set of studies organized by Susan Gal and Gail Kligman on gender and postsocialism (2000). Robert Van Kemper and Anya Peterson Royce (2002), in their volume on long-term field research in anthropology, trace the development of field-research strategies from solitary ethnography to collaborative and advocacy approaches.

Collaborative research involves shared management and direction of a research project among the scholars and the subjects of the research. For example, in her research on the environmental and community damages suffered by the Marshall Islanders from nuclear bomb testing, Johnston worked with a colleague, Holly M. Barker, who specialized in the area, as well as members of the community as coproducers of knowledge. Participatory action research-which involves collaboration on the goals of project, the methods of research, and the analysis of the findings-is another example of this form of collaboration and one where the goals of the group supersede those of the individual anthropologist.

Luke Eric Lassiter (2005) argues that collaborative ethnography is another powerful way to engage the public. Through undertaking fieldwork and the writing of ethnographic texts with those whom he studies, he is able to pull together academic and applied anthropology efforts to be more directly involved. He points out that as anthropologists in the 1960s 
and 1970s struggled to integrate theory and practice in order to create a more engaged and activist anthropology (Hymes 1969; Peacock 1997; Sanday 1976), the applied anthropologists were developing collaborative ways of working (Schensul and Schensul 1978, 1992; Stull and Schensul 1987). Merrill Singer (1990, 2000) contends that reinventing "public anthropology" is simply another example of how the hierarchies of academic/applied and the hegemony of academy anthropology marginalize applied/practicing anthropology's long history of public work.

Collaborative strategies are the hallmark of much of applied research and practice (Stull and Schensul 1987). Collaborative models of research and action (Schensul and Schensul 1978) are utilized and modified by medical anthropologists, such as Linda Whiteford (Whiteford 2009; Whiteford and Tobin 2007) and Noel Chrisman (2005) among many others, who employ collaborative strategies in their community-based health interventions and public-health research. Leith Mullings with Alaka Wali, Diane McLean, Janet Mitchell, Sabiyha Prince, Deborah Thomas, and Patricia Tovar (Mullings et al. 2001) collaborate as a team of researchers and with Harlem community members they address health inequalities and develop an intersectional perspective on health (Mullings 2005). Some anthropologists have been more interested in "agency" and health entitlement as a way to integrate collaboration in their practice (N. Taskima, personal communication), while Shirley Fiske (2009), through collaboration with legislators from her perspective working on Capitol Hill, encourages anthropologists to engage more directly in policy making. Setha Low, Dana Taplin, and Suzanne Scheld (Low, Taplin, and Scheld 2005) worked with National Park Service employees, park managers, park and beach users, local residents, and community groups to develop collaborative activities, research techniques, and workshops to reach a broader public in their cultural diversity studies. And although we do not review the many archaeological contributions to public and engaged practices, it seems important to note that most archaeological practice, cultural resource management, historic preservation, and public history projects, such as the ongoing work of T. J. Ferguson and Chip Colwell-Chanthaphonh (Colwell-Chanthaphonh and Ferguson 2006a, 2006b, 2008; Ferguson and Colwell-Chanthaphonh 2006), focuses on the collaboration of the archaeologist with the local descendant communities to define and protect their ancestral places. This is research that can only be done collaboratively and provides a model, much like Lassiter's collaborative ethnography, for the future.

\section{Advocacy}

Another dimension in engaged anthropology is advocacy. Some examples of this diverse field are working to assist local communities in organizing efforts, giving testimony, acting as an expert witness in court, witnessing human rights violations, serving as a translator between community and gov- ernment officials or corporations, and helping local groups use international principles such as human rights by working to vernacularize them. Stuart Kirsch (2002) asserts that advocacy is appropriate within anthropology, especially as it seems like a "logical extension of the commitment to reciprocity that underlies the practice of anthropology" (178). Many anthropologists work with indigenous people-translating their grievances into forms that can be heard outside the community, such as by an international tribunal-and serve to increase legal pressure and public scrutiny (Hale 2006; Kirsch 2002). Anthropologists have a long history of serving as advocates for indigenous peoples. For example, in the early years of protest against the construction of a massive complex of dams on the Narmada River in India, a project that displaced large numbers of people including many tribal peoples, the World Bank commissioned the anthropologist Thayer Scudder to carry out an appraisal of the resettlement process. His report, based on a 1983 visit, was critical of the government's resettlement efforts (Khagram 2002:211). In 1984, Scudder worked with a transitional coalition of local and international NGOs to improve resettlement policies, meeting with local villagers and activists to find out what they wanted in order to develop an agreement with the World Bank, which was funding the project at the time. Other NGOs joined the effort to claim that the resettlement was illegal because it violated International Labour Organization (ILO) Convention 107, which acknowledges the right of tribal peoples to their traditional lands or equal land if they are removed (Khagram 2002:212-213). In this case, the anthropologist acted as an intermediary between tribal peoples, the Indian government, the World Bank, and international regulations such as the ILO convention and became an advocate for their perspective. Signe Howell's history of Norwegian anthropological activism shows that the defense of indigenous peoples has played a similarly galvanizing role in that country (Howell 2010).

Several articles in this collection describe advocacy anthropology. Barbara Rose Johnston describes her work on behalf of the Marshall Islanders as an expert seeking to document the biocultural effects of nuclear weapons testing in the islands (Johnson 2010). She worked to gather data and facilitate participation in decision making and remediation in support of a claim for damages before the Marshall Islands Nuclear Claims Tribunal. She and her team used collaborative and participatory methods to develop an understanding of community damages and remedial needs beyond economic compensation for damages and loss of property rights, ultimately winning a significant judgment. As Ida Susser describes her work on AIDS in South Africa, she shows how the urgency of dealing with suffering and disease lead her to take an advocacy stance toward the provision of treatment (Susser 2010). Michael Herzfeld describes his role in helping a small community in Bangkok protect its housing from redevelopment destruction. In the midst of the competing ethics of development and housing rights, Herzfeld chose to work to- 
ward preservation of housing on behalf of a poor and vulnerable population (Herzfeld 2010). When Merry was doing research on gender violence and human rights at the $\mathrm{UN}$, she became an advocate for intervening to prevent gender violence, helping to draft documents promoting gender violence as a human rights violation. As she visited gender violence programs around the world, she shared information about the organization and strategies adopted by other programs (Merry 2005, 2006). Low (2008), working with local groups to protect public space through radio talk shows, newspaper editorials, public lectures, tours, and as an artist through her public art work, has become a well-known advocate for protecting public space in New York City.

\section{Activism}

Advocacy is not easily distinguished from activism. Both can draw on a person's knowledge and commitments as an anthropologist, but activism also builds on commitments as a citizen or as a human confronting the violations or suffering of other humans. Barbara Rose Johnston proposes the concept of the "anthropological citizen," the anthropologist who serves as a scribe documenting abuses and as advisor, advocate, and partner in advocacy (Johnston 2001a, 2001b, 2006, 2010). Contemporary anthropological activism takes the position that anthropologists are "responsible for the potential effects of the knowledge produced about people and their cultures, to contribute to decolonizing the relationship between researcher and research subject ... and to engage in a form of anthropology that was committed to human liberation" (Speed 2006:67). Charles Hale defines "activist research" as "a method through which we affirm a political alignment with an organized group of people in struggle and allow dialogue with them to shape each phase of the process" (Hale 2006:97). Both Speed and Hale, as well as Sanford and Angel-Ajani (2006), argue that activism is different from critique, especially cultural critique, in that scholars who practice as activist researchers have dual loyalties, to their discipline and/or academic community and to a political struggle (Hale 2006:100). For those activists who work for a government agency, NGO, or as an independent contractor, the question of loyalty becomes even more complex in that there is also a commitment to a client or funder as well as to the discipline and the identified struggle.

There are many excellent compilations and examples of activist work. The most well-known is Engaged Observer: Anthropology, Advocacy and Activism, edited by Victoria Sanford and Asale Angel-Ajani (2006), which focuses on cases of the contradictions that anthropologists face in places torn by war, violence, and intergroup conflict. Another example is Shannon Speed's (2006) work with an indigenous community in Chiapas, Mexico. When she found that the community was very concerned about protecting its land rights, she worked with them to show them how to define themselves as an indigenous community and to present themselves to the ILO in order to use claims to collective cultural rights to protect their lands and resources. Taking a slightly different approach, Nancy Scheper-Hughes (1995) argues that anthropologists have a duty in their field sites to act in situations of suffering even when the other participants object (see also 1992).

In practice, academic and activist endeavors are never autonomous, despite our analytical assumptions of separateness. For example, the ethnographic study of human rights practices continually reveals the porosity of borders between academic and activist work. As anthropologists move into new fields of research such as human rights, they encounter subjects who themselves employ anthropological concepts and engage in theoretical debates about what they mean. They debate what culture is, how to define gender, how globalization affects women, and how a human rights approach can increase women's safety. They are self-reflective, analytical, and participate in the same intellectual world as anthropologists. Anthropologists play important roles in this world as advisors, consultants, and advocates, particularly in the area of indigenous rights. Although at times during the twentieth century, anthropologists struggled to assert their status as scientists, seeking to stand outside moral debates, a position clearly articulated in the 1947 statement of the executive board of the AAA condemning the Universal Declaration of Human Rights (Goodale 2006a, 2006b; Merry 2001), this stance has changed significantly.

Indeed, some anthropologists question the viability and moral acceptability of a nonactivist stance. They argue that the implications of ethnographic detachment in a world characterized by resource inequalities, "land grabs," and political violence are problematic. Under these circumstances, ethnography cannot be apolitical, and even inaction, such as not assigning responsibility to an oil company for its destructive activities, is itself an action, as Kamari Clarke (2010) argues. The absence of public action is not neutral, and to rely on anthropological principles limiting ethnography in contexts of conflict or war is itself a political act. As Jackson argues, we have ignored the ambiguous relationship between anthropology and activism in the ethnographic encounter and even in our teaching and graduate student training to the detriment of our analysis and our politics (Jackson 2010).

Clearly, there is a long tradition of engaged anthropology and a wide variety of forms of engagement in the discipline. But the florescence of engaged anthropology is not without problems. The following section discusses three dilemmas engaged anthropology faces.

\section{The Dilemmas of Engagement}

These three dilemmas grow out of questions about how, when, and to what extent anthropological work should be engaged. They have been areas of debate in the past, and they continue to be points of contestation in the present. There are no easy answers to the dilemmas they pose.

The first dilemma concerns the extent to which the re- 
searcher should act as a participant, including becoming engaged in activism that seeks to reform features of social life to enhance social justice rather than being a disengaged outsider observing and recording social life. Some argue that participation of this kind changes the society being studied and question the ethical right to seek to change other ways of life. Others argue that those who fail to respond to the need for intervention are acting unethically. Some point out that all societies are now economically and politically interconnected such that isolation is not a possibility, and many suffer from the effects of this interconnection. How, and to what extent, the anthropologist should seek change is uncertain. There is a long history of debate on this point, and it is far from settled now. Interventions are often justified on the basis of universal principles of justice, but this seems uncomfortably close to arguments about the imperial "civilizing process" or the mandate of Christian missionaries to convert the "heathen." Several of the articles in this issue express concern about intervening in other societies, including Ali (2010), Susser (2010), and Herzfeld (2010), but they turn to universal discourses of social justice such as human rights to justify their intervention. Clearly, this issue underlies many of the debates about activism described above.

The second dilemma is the desire to criticize those who wield power over others unjustly in postcolonial societies while avoiding replicating colonial relations of power. For an anthropologist of the nationality of the imperial power to criticize a postcolonial government newly escaped from the control of that power seems to replicate colonial inequalities. Alan Smart articulates clearly the difficulties he, as an outsider, experiences in criticizing the government of Hong Kong under postcolonial conditions. In his research on squatter housing, with its history of British colonialism, he felt the need to use tact when doing social critique. For example, in his effort to criticize the operation of the housing market in Hong Kong, he confronted the difficulty of not feeling that he knew the right approach. He concludes that it is more useful not to be arrogant in critiques and perhaps best to restrict critique to one's own country (Smart 2010).

The third dilemma is the desire to promote social justice and ameliorate the suffering of war and conflict by providing anthropological insights and techniques to governments and the military while avoiding co-optation and misuse of anthropological methodology and expertise. To work with a government, military, or development agency offers the promise of rendering the work of these agencies more humane and responsive to community concerns and perspectives but risks losing control of the way research is used and manipulated. Refusing to work with these organizations denies them the benefit of anthropological insight and may hinder their ability to understand local communities and cultural practices. On the other hand, working with them poses challenges of avoiding co-optation and the ethical problems articulated by the AAA statement opposing the HTS. Clearly, to what extent anthropology should, as a discipline, participate in military endeavors, has been debated at least since World War II.

Jonathan Spencer illustrates this dilemma clearly, describing how an initiative of the British government that appeared at first to provide an opportunity for anthropological contributions to understanding other societies became a project antithetical to anthropological principles (Spencer 2010). The British Foreign Office sought to fund research on Muslim terrorism in collaboration with the United Kingdom's Economic and Social Research Council, the major academic research funding body. This collaboration created a highly problematic framework for research. Spencer describes the pitfalls of the funding arrangement and the increasing opposition of scholars in the United Kingdom to the project. But not all participation with government-sponsored research is ethically problematic. Kamari Clarke distinguishes between providing general knowledge to the army versus specific knowledge of persons and activities (Clarke 2010). Generic knowledge can be productive of better relations between the military and those under its control, while specific knowledge can be harmful to those it reveals. She argues that disengagement from the military is not the only stance for anthropology, but that it needs to engage this site of power as well. Not only is there a danger of engagement, but there is also a danger of disengagement. Clearly, it is important for anthropologists to study phenomena such as the emerging security apparatus in the United States (Fosher 2009).

\section{Barriers to Engagement}

Despite the range and strength of engaged anthropology, some of these forms of engagement face obstacles and difficulties in the form of intellectual and organizational barriers. Many of these hindrances are institutional, including the practices of funding agencies, hiring, tenure, and promotions rules, while others are conceptual, such as ideas of "science" rooted in anthropological history. Departmental or university norms along with corporate and company norms of what constitutes a legitimate work product, guidelines of what is publishable, the organization and structure of professional meetings, and the funding rules of granting agencies contribute to silencing advocacy and activism. These forms of silencing need to be discussed within the discipline and our graduate training programs so that we are better prepared to recognize and confront these obstacles and tackle the dilemmas above so that anthropological training can contribute more fully to the public realm.

The inability to talk or write about a political agenda even though political engagement is essential to the fieldwork. This inability to speak occurs when the people studied or worked with hold fundamentally different values from those of the anthropologist. Especially when "studying up," such as when interviewing middle-class white residents of exclusive cooperative apartment buildings or gated communities, the agenda of 
the researcher may differ from that of those being interviewed (Low 2003, 2010). When interviewing gated-community residents, Low had a difficult time because her informants assumed that she held the same values as they did. She wanted to remain honest and open about her research findings that were critical of private housing schemes with both the residents and the public. She struggled to write a book that presented her informants' lives fairly but also offered an adequate critique to allow readers to reflect on the way that these communities are changing the housing landscape. The threat of silencing was always present as she searched for a way to present findings that were unpopular with her gated-community residents without compromising her agenda to uncover the social consequences of gating. In practice, anthropologists often confront the challenge of gaining access to research sites that require some forms of self-silencing as the price for working there.

The expectation that anthropological work be scientific, objective, and neutral rather than humanistic and personal. This often means presenting work in theoretical terms, sometimes with heavy use of jargon. Anthropologists who are interested in activism and critique are deterred from presenting their knowledge in forms that are readily accessible to the media and make a strong advocacy statement. In the field of human rights, for example, activists present knowledge for public consumption in quite different ways from anthropologists working on the same problems. Even though human rights activists and scholars rely on similar forms of data collection-such as surveys, personal narratives, and case studies - human rights advocates tend to present this knowledge in relatively stark forms in order to generate outrage and action from the public. They often rely on compelling personal accounts with simple story lines of suffering and individual responsibility supported by statistical documentation of the extent and frequency of the problem rather than presenting situations in terms of nuance and complexity framed by context and history. To be persuasive to the general public, narratives need to be straightforward and emotionally engaging. To be persuasive to an academic audience, they require nuance and intricacy. Outrage and moral judgments must be muted if they appear at all. Human rights activists frame their stories in universalistic terms; anthropologists present more contextually specific accounts of social injustice with less possibility of resolution. Although this introduction and collection indicate that norms of academic publication are changing, there are still issues with the presentation of knowledge that mute activist scholarship.

An emphasis on particularity and context, on reading each situation in terms of the variety of ways people live in it. This puts anthropology at odds with several universalizing discourses of importance to the field. Even though anthropological scholarship is increasingly engaged with universalizing discourses of reform, such as human rights and international humanitarianism, it resists universals. Such frameworks pro- mote an ethical stance that is unabashedly universalizing and offers an important resource for many of the peoples anthropologists study. However, supporting the right to difference, grounded in the scholarship of the colonial era and resistance to its imperialist demands for change, continues to influence the discipline. At the same time, supporting political initiatives of subordinated groups that see possibilities of audience and resource support in adopting this universalistic language is critical to anthropologists. Insofar as ethnographic practice includes an implicit commitment to the well-being of its subjects, anthropologists tend to promote mobilization of whatever resources are available. Insofar as they seek to protect the right to cultural difference, these connections are problematic.

The expansion of international discourses of social justice. This poses a major challenge to anthropological scholarship. Such discourse frames experiences in universalistic terms, flattens difference, and focuses on individual injuries rather than structural violations. Anthropologists play a critical role in translating between these universalizing worlds and the particularities of community and neighborhood experiences to generate effective forms of communication for a variety of audiences as well as for advising on political strategy. However, as universalizing languages become more dominant in policy and public discussion, anthropological knowledge premised on specificity and context can be marginalized. As James Ferguson notes, for example, discussing Africa as a whole appeals to a broader audience than a more focused case study (Ferguson 2006).

The concern with avoiding the appearance of imperialism given the postcolonial consciousness of anthropologists. Anthropologists working outside of their own geographical or national regions often self-silence because they fear being considered a missionary or colonialist and are therefore reluctant to criticize societies or governments other than their own, as Smart argues (2010). Given the historical collusion of anthropology and colonialism, it is important to refrain from colonialist critiques of other countries. Indeed, even progressive human rights discourse has some parallels with the "civilizing process" in that it is a project of the former colonial powers to improve the "culture" of their former colonies. The discipline's emphasis on local knowledge and agency runs against the desire to critique the institutions of postcolonial societies.

Institutional pressures connected with promotion, tenure, and access to funding. These pressures sometimes emphasize writing in arcane theoretical terms rather than in forms that are more amenable to popular audiences. Moreover, because systems of promotion and tenure depend on the production of publications, particularly in peer-reviewed journals, anthropologists are constrained to conduct research that will enable them to publish in such journals in ways that satisfy their peers. Insofar as publication depends on field research, which requires financial support, anthropologists must seek external funding in support of their work, which provides another 
constraint on field research. Some funding agencies emphasize neutral, scientific-appearing work over work that has a clearer activist agenda. Some government and corporate funding comes with requirements of secrecy in the use of the data or forms of reporting that could negatively affect the communities where anthropologists work and may violate ethical standards of anthropological research. Such forms of research are particularly common in conflict zones. Under circumstances of war or concern about terrorism, funding may be directed to particular political or military objectives, as in the example of the HTS.

Similarly, the U.S. government has not only generously funded the HTS system, it intends larger investments in anthropological work through Project Minerva. The AAA argued that these funds should be distributed through the National Science Foundation process of academic peer review instead of through the Department of Defense, but even a peer-review process does not deal with the problem that this is research with a particular military and political agenda. Clearly, anthropological scholarship that depends on funding is to some extent bound by the expectations and goals of the granting agency. The same problem confronts social activists, who must not only frame their projects in terms the granting agency approves but must also provide evidence for their accomplishments. As ethnographic research depends increasingly on defense and security funding, these issues will only become more complicated.

\section{Conclusion}

This volume argues that engaged anthropology has many faces, from emotional support in the course of field research to activism to promote the human rights of vulnerable populations. Within U.S. sociocultural anthropology, the spread of engaged anthropology is extensive, while the contributions of Howell, Smart, and Spencer indicate that similar issues are important in Norwegian, Canadian, and British anthropology. This is hardly a new endeavor for the discipline; as the historical section shows, there is a long history within anthropology of addressing social problems and developing social critiques of the structures that subordinate individuals and groups. Engagement is transforming the way anthropologists do fieldwork, the work they do with other scholars and with those they study, and the way they think about public as well as scholarly audiences.

Our undertaking here has been to assess the state of the field of engaged anthropology and to expand its scope. We wanted to broaden the range of what we consider engagement, showing how pervasive engagement is within anthropological scholarship. Our introduction and the articles attempt to illustrate this breadth and richness through an expanded set of forms of engagement that is more inclusive, from basic commitment to our informants, to sharing and support with the communities with which we work, to teaching and public education, to social critique in academic and public forums, to more commonly understood forms of engagement such as collaboration, advocacy, and activism. The articles reveal this broad range of forms of engagement, from concerns about tact and ethnographic critique to direct advocacy in favor of subordinated communities.

We were also interested in highlighting the tensions and ambiguities inherent in this project. For example, the articles show that engagement raises dilemmas for ethnographic research and writing for both practicing and academically employed anthropologists. Many of these dilemmas have been with the field for a long time, such as the ethics of intervention into a research situation, the appropriateness of critique given the anthropologist's position as insider/outsider, and the hazards of working with powerful government and military organizations.

The articles in this special issue demonstrate widespread enthusiasm for a variety of forms of engaged anthropology along with some enduring ambivalence about engagement and a continuing set of obstacles and forms of silencing faced by those seeking to develop a vibrant, engaged anthropology. Finally, the articles not only reveal ambivalence but also highlight the obstacles and organizational barriers to engaged work. These include institutional dimensions of universities and the world of practice, such as the inability to talk or write about a political agenda; the expectation that work be scientific; anthropological emphasis on particularity and context; avoiding an imperialist stance; and problems with promotion, tenure, and recognition of scholarship. Yet despite these difficulties, engaged anthropology is alive and developing in many different ways that we support and herald as an intrinsic part of a vibrant and interconnected anthropological future.

\section{Comments}

\section{Mark Goodale}

Associate Professor of Conflict Analysis and Anthropology, George Mason University, 3330 North Washington Boulevard, Arlington, Virginia 22201, U.S.A. (mgoodale@gmu.edu).

Setha Low, Sally Engle Merry, and contributors revisit the problems and possibilities of "engaged anthropology" in this comprehensive and indeed landmark collection of articles, which resulted from a 2008 Wenner-Gren Foundationsponsored international conference. The editors' introduction to this special issue of Current Anthropology makes a range of important contributions to the history and historiography of the anthropological presence in the public sphere, and their innovative theorization of this often fraught presence must now serve as a benchmark going forward. As the editors rightly argue, now is an ideal time for anthropologists to reconsider both critically and creatively the multiple dilemmas 
that confront those of us who seek to find ways to bring the unique and often ambiguous ways and means of anthropology to bear on some of the contemporary world's most pressing problems, including endemic poverty, structural violence, ethnic and racial discrimination, the rise of transnational criminal networks, and the deepening of various forms of marginality within those Fergusonian "global shadows" that are a necessary by-product of the consolidation of late (perhaps even decaying) capitalism.

I would characterize the overall tone of this major intervention as one that moves between guarded optimism and profound ambivalence about the challenges facing anthropologists who struggle with ways to bridge the often artificial divide between scholarship and the world. Indeed, as the editors explain, this "rich panorama of anthropological work" can and must be both intellectually vital and ethically consistent with the still-emergent standards of professional anthropological practice. Yet what is strikingly absent here is the kind of full-throated and passionate triumphalism that is to be found in some of the earlier writings on this topic. Readers coming to this collection hoping to find an uncomplicated blueprint for anthropology as political action will be disappointed; so too will those younger scholars and graduate students seeking epistemological solace in these dystopic times in which the promises of the early post-Bush II years have yielded to the sober realization that "plus ça change, plus c'est la même chose."

What this collection offers instead is both a framework for understanding and an argument for why more anthropologists should reframe their scholarship as some form of engagement. In their introduction the editors unpack "engagement" through a clear-eyed and judicious conceptualization that leaves room for vigorous debate and further refinement. They distinguish between six modes of engagement that are relevant to the work of anthropology in all of its diversity: sharing and support, teaching and public education, social critique, collaboration, advocacy, and activism. Although the editors modestly describe these divisions as a "preliminary typology," the articles in this issue demonstrate that this framework can both capture and, in a sense, justify an important cross section of the leading edge of contemporary sociocultural anthropology.

At the same time, what the editors describe as barriers to these modes of engagement are all too real and must be acknowledged. These barriers are likewise diverse and confront anthropologists with epistemological, institutional, political, and (especially for American scholars) geopolitical challenges. In other words, despite the intellectual allure of an expanded conception of engaged anthropology, there are reasons why some anthropologists do not formally recast their teaching and practice in these terms. This collection demonstrates that what might be thought as an unengaged anthropology should not necessarily be reinterpreted as bad faith or as a symbol of narrow professional self-interest. Indeed, given the extent of the dilemmas for engaged anthropology that the editors describe in convincing detail, such a reframing becomes something of an act of courage. Yet what this collection also demonstrates is that such acts of courage will continue to be "an intrinsic part of a vibrant and interconnected anthropological future" and much of what is best about our inimitable discipline.

\section{Catherine Lutz}

Department of Anthropology and Watson Institute for International Studies, Brown University, Box 1921, 128 Hope Street, Providence, Rhode Island 02912-1921, U.S.A. (catherine_lutz@brown.edu).

Low and Merry have written a comprehensive and careful survey detailing the efflorescence of an engaged anthropology, and it provides cause for celebration. The discipline's newly wide-ranging enthusiasm for making anthropological research and writing relevant to pressing global problems comes after a sometimes painful period of anxiety and disciplinary self-critique. That period in the 1980s and into the 1990s produced angry retrenchment into positivism in some corners and demoralization in others. The subsequent engagement with publics and the tackling of pressing human concerns, while not new as Low and Merry point out in their historical narrative, has given anthropology new life and reason for being.

Low and Merry define an engaged anthropology primarily via a six-part typology, including sharing commitment and resources; educating a variety of publics; identifying inequalities, suffering, harms, or discriminatory concepts; collaborating in research or action; advocating; and engaging in activism (though the value of the distinction between these latter two is not clear). Like a number of earlier commentators, Low and Merry write not simply to describe this trend but to valorize it and to help make this kind of anthropology more central to the discipline and more acceptable to those who broker careers in the academy.

They also argue for the value of making this kind of anthropology more recognizable to broader publics. Those publics are most often exposed to expertise on human behavior that reflects a "growing tendency to understand behavior in broad, comparative, and statistical terms" as well as, we can add, in deterministic biological (your genes make you do it) or economic (the market makes you do it) ones. Perhaps even more important is the ability of engaged anthropologies to highlight and make sense of popular experiences, desires, and misunderstandings of things such as inequality, environmental racism, or job and status loss. This ability to claim research-based knowledge is especially valuable in a historical era when public debate is so often run on discourse produced via the science of public relations and political expedience, both of which merely produce info-kibbles or sound bites. 
Low and Merry write a very valuable account of the historical emergence of various forms of engagement from the discipline's national beginning. Their account of the marginalization of women and minority anthropologists notes that those scholars' typically more critical stance was blocked from contributing more to, or speeding the emergence of, a publicfacing and collaborative anthropology. Even with their belated and/or partial entry into the university, the deradicalizing effect of working there continues for all of its denizens and represents a countervailing trend.

Anthropology in the United States is engaged with the world from within the constraints not only of our institutional locations but also of our cultural discourses. How to speak outside those constraints, while still being understood or getting uptake, could be added to the three dilemmas of engagement that Low and Merry ask us to consider. The dilemmas they identify include whether to participate in change efforts, whether to criticize the powerful in the Global South and risk replicating colonial modes of thought and action, and whether to provide knowledge and other assistance to governments, including the military, or risk the misuse of that knowledge.

In the third of these cases, we can see the limits placed on our thinking by a highly militarized end-of-empire discourse in the United States. That discourse continually suggests that the U.S. military is a tool for providing security to domestic and foreign populations as well as to others, albeit a tool occasionally misused or tragically failing to accomplish its intended aims. That discourse suggests that neither a "humane military" (as opposed to humane people in uniform) nor "humanitarian warfare" are oxymorons. Such assumptions would have little traction in the face of research that focused on body counts, environmental damage, ideological constructs, or the size of the military budget for weaponry.

As this example shows, the concept of engagement can easily lose its critical edge and simply become synonymous with "relating to" or with "working for" anyone or any institution. Anthropologists could be said to "engage with" advertisers or manufacturers of any type of consumer product from tobacco to baby formula. So the argument is made in this introduction and special issue of Current Anthropology that proper forms of engagement include providing general knowledge to the military in order to encourage them to treat the people of their occupation zones better. The military's paramount mission of winning the wars assigned to it by civilian elites becomes deeply confused with its public relations face. In what other world than the U.S.-centric and discursively limited one does this view of what anthropology can accomplish within the military make sense?

As informants become colleagues and allies in research and their voices become more integral to our conversations, such arguments will hopefully lose their force, and the larger project of an anthropology at work against the harms and injustice of our contemporary world will continue to grow and make a difference.

\section{James Peacock}

Department of Anthropology, CB\#3115, 301 Alumni Building, University of North Carolina at Chapel Hill, Chapel Hill, North Carolina 27514, U.S.A. (peacock@unc .edu).

This essay contributes an excellent and insightful overview of engaged anthropology to date; I applaud what is said and also suggest a further dimension: engaged anthropologists. Why distinguish engaged anthropologists from engaged anthropology? Because anthropologists as human beings, citizens, and in other roles often become engaged in ways that go beyond our discipline as well as engage it with the world.

To illustrate, consider a simple two-by-two table. One dimension is "Anthropology plus and minus" and the other is "Anthropologist plus and minus." Thus, we have four combinations.

$\begin{array}{lll}\text { Anthropology } & \text { plus } & \text { minus } \\ \text { Anthropologist } & \text { plus } & \text { minus }\end{array}$

1. Anthropologist plus/anthropology minus. "Minus" is misleading, but in this combination, the discipline is emphasized less than the contribution of the person. Johnetta Cole is a superb example. Johnetta is indeed an anthropologist by training and orientation, but she has contributed strongly beyond anthropology as a college president, public intellectual, and brilliant commentator and speaker in a wide spectrum of contexts that transcend the discipline of anthropology. She as a person who draws on and deploys a much wider repertory than that offered by our discipline.

2. Anthropology plus/anthropologist plus. Here both the person and the discipline are emphasized. When doing fieldwork with the Muslim movement Muhammadiya in Indonesia, I was asked by a tribunal, "What is your religion?" I replied, "My religion is anthropology (ilmu Kebudayaan)." I affirmed a disciplinary identity rather than a conventionally religious identity, or rather I categorized a discipline as a religion of sorts; that is, I claimed to be devoted to ethnography as opposed to espousing some particular religious belief. Here I emphasized a disciplinary identity as part of my own identity.

3. Anthropology plus/anthropologist minus. The Human Terrain System employs 405 persons who are "embedded" with military units in Afghanistan. These persons reportedly follow an anthropological approach to research on local contexts, yet only five of the 405 are reported to be anthropologists. Here the discipline rather than the person's training or professional or private identity is emphasized.

4. Anthropology minus/anthropologist minus. I served as chair of the faculty senate of the university where I work. The 3,000 faculty whom I represented come from many disciplines and professions in 14 schools ranging from medicine and law to arts and sciences. Neither my discipline nor my professional identity as an "anthropologist" played much of a role in my 3 years as chair any more than did the discipline or identity 
of my predecessor, a microbiologist. For each of us, the key considerations were governance; issues including curricula, economics, and ethics; relations to the legislature, etc. It so happened that we came from different cultural backgrounds as well as disciplines (he is a Yorkshire, U.K., native), but this mattered little compared to the mechanics and politics of both the university and the state. I had to deal with these, for example, in order to obtain a legislative appropriation that continues to result in millions of dollars in tuition reductions for out-of-state, including international, graduate and professional students.

Of course, there are gradations between plus and minus. Here is an example that might be termed anthropology moderate/anthropologist moderate in that discipline and disciplinary identity played a modest role in a person's "engagement." Here, the task was to internationalize a state university that was largely state and regional in focus. I undertook this task as a director of international programs. My nine-step plan entailed numerous program initiatives, including constructing an 83,000-square-foot building to house them. This was made possible by a statewide bond package that was voted in unanimously by all 100 counties of the state and that resulted in building on 16 campuses and many community colleges. My contribution drew moderately and occasionally or subliminally on anthropology and experience as an anthropologist, but neither aspect was or could be prominent in the effort because the focus was sharply on the overarching goal of "internationalizing."

What, then, can either anthropology or the anthropologist contribute to engagement? My impression is that the single strongest asset is holism. Holism includes an awareness of broader and immediate contexts and a certain agility in dealing with contexts. However, holism must be trumped by engagement if, in fact, engagement is the objective. The engaged anthropologist, like any other engaged human, has to focus on goals and means, which includes determining when and where anthropology is enriching and when it is not. For example, ethnography is often not plausible because action is needed quickly and observation must be curtailed or be included as part of the action at best. Also, leadership may require setting aside anthropological proclivities to look and listen rather than engage and change. The distinction between anthropology and anthropologist reminds us of both tension and productive interplay between our discipline and the engaged practitioner.

\section{David H. Price}

Department of Anthropology, Saint Martin's University, 5300 Pacific Avenue, Lacey, Washington 98503, U.S.A. (dprice@stmartin.edu).

Low and Merry's article set me thinking about the borders between engagement and disengagement and how the margins housing "activism" mark it as distinct from whatever unac- tivism (passivism?) might be called. As I work on a large historical project connecting various anthropological research projects during the Cold War to the political economy in which this research was embedded, I come to see common notions of "engagement" and "disengagement" as distinctions that can decrease in utility as historical distance increases. Just as most British ethnographers working under colonial authorities in the early- to mid-twentieth century did not selfconceive themselves as primarily engaged with the dominant processes of colonialism, many anthropologists in the recent past were funded for research that appeared removed from direct "engagement" (in the ways we frequently consider many applied projects to be "engaged"), yet when the larger political economic forces are considered, many of these projects had their own engagements in ways that are seldom considered.

Some of these connections are as tenuous as the general shifts in funds to study languages and culture regions of pressing interest to American "national security" as political forces dump funds for a wide range of study in particular geopolitical areas of interest to American foreign policy. These political forces garner attention when they fund obviously more directly engaged things such as counterinsurgency research, but they also fund less directly engaged things such as obscure kinship analysis, art forms, or myths in regions of future geographical interest in ways that add to the brain trust. The macrotrends funding one geographic region over another rise and fall with geopolitical shifts, and these shifts produce differing stocks of scholars whose geographic expertise is an artifact of geopolitical interests in ways that can be seen in the shift in funds for language study over the decades as politically driven waves have shifted from Russian and Spanish to Farsi, Urdu, and Arabic. In some sense, the funding of even the most obscurely theoretical research is enmeshed in a political economy that dictates these funding trends regardless of how directly removed from political policy their work is (Price 2003). But there were also many other projects in which anthropologists unwittingly directly engaged in political work that they did not conceive of as "engagement" for reasons ranging from being lied to by funding sources (Price 2007) to disciplinary political naivete (Geertz 1995; Nader 1997).

I would not argue that distinctions between engagement and nonengagement do not have some utility; I would instead raise questions about how clearly such delineations can be made. Perhaps disengagement is not possible insofar as whatever an anthropology of neutrality or disengagement is, it is an anthropology engaged in supporting the status quo.

In a similar way, "activism" needs some unpacking. "Activism" is a loaded term, and exactly what is and is not activism is not clear. I suspect that activism is only the name we give to those opposing policies and programs undertaken by those with power; it is rare to hear the term used for anthropologists working in the interests of powerful organizations such as the World Bank, the International Monetary 
Fund, or the Central Intelligence Agency, though these roles logically can and do exist. This same dynamic was found in the early twentieth century, when Madison Grant's "racial science" was viewed part of the nonactivist status quo and Franz Boas's research was considered to be an activist science. Boas was not advocating his position any more than Grant was advocating his, yet Boas is considered an activist because his position threatened the racialized stratification justified with Grant's foolishness. Activism per se has nothing to do with the quality of one's work (these standards are generally measured by such criteria as standards or reliability, validity, etc.); it has to do with opposition to power. Answers to questions of whether or not anthropologists should be activists depend on how amenable to change "power" is in a given situation.

The "institutional pressures connected with promotion, tenure, and access to funding" discussed by Low and Merry significantly influence what is and is not considered "activism." The authors correctly observe that the pressures regulating tenure, promotion and funding "emphasize writing in arcane theoretical terms rather than in forms that are more amenable to popular audiences"; and I would add that the more arcane the writing, the further it is likely to be from engaged forms of activism.

The question is not whether or not anthropologists should "engage"; we are all engaging in some way or another. I fully realize that when I research and write about anthropology and military and intelligence agencies, I am engaging with the Pentagon, the CIA, the public, critics, and others. For me, the fundamental issues begin with being clear about the political issues raised by any work we undertake and taking steps to see that, whatever our political position, ethical standards of the discipline and met and upheld.

\section{Jamie Saris}

Department of Anthropology, National University of Ireland Maynooth, County Kildare, Ireland (ajamie.saris@ nuim.ie).

Most of the authors in this collection see a continuity in anthropology between the rapport that allows fieldwork to occur and a political stance in favor of the community of study. The primary sense of engagement detailed here is in a status sense downward. For the most part, we find an educated, more powerful anthropologist "witnessing," "giving voice," or "advocating" for the less powerful. Thus, a few kinds of scenarios dominate the discussion. The first involves a marginalized community at some stage of organization against the encroachment of state and corporate power. This engagement often results if not in strategic victories then in tactical delays, where a rough balance between forces can be struck, sometimes resulting in the de facto or de jure development of a "community" NGO as a "recognized person" in the struggle (Herzfeld 2010 tracks just such a situation). The second involves how "traditional" forms of inequalities have been sharpened and even made lethal under the changes wrought by global capitalism and the ethical-political difficulties this situation poses for the ethnographer (e.g., Ali 2010). A third kind investigates how the funding of research interests highlights and makes sharper extant divisions within a society, especially at a moment when the term culture has been invested with extraordinary explanatory power in several discourses outside of anthropology (Spencer 2010 and to a lesser extent González 2010 are in this vein).

Of course, there exists a very different form of engagement in anthropology: instead of the anthropologist going literally or figuratively abroad and serving (heroically or no) another community, we do not need to look far back in the history of the discipline to find anthropologists, after finding dysfunction in their communities of study, suggesting an engaged response completely at odds with the tone in this issue. Turnbull's grim recommendation for the Ix, for example, at the end of The Mountain People, or Jules Henry's devastating critique of the U.S. family in Culture against Man are examples of strongly antirelativist stances in the largely disengaged period in Low and Merry's epochalization of the anthropology.

On the other hand, other anthropologists have come home, after studying some of the variety of human life, and find, in Mauss's phrasing, that they have "great possessions to defend." In the recent past, some of these have become public intellectuals but in a way that most of the AAA would rather not know about. Thus, some of the most active "scholarly" voices in the so-called culture wars in the United States, such as Stanley Kurtz (a stalwart for the National Review), claim to have PhD's in anthropology and expressly use their fieldwork experience in service of their restrictive understanding of, for example, marriage or the family. Howell's (2010) reading of the Norwegian academy, in the wake of Wikan's very controversial book Generous Betrayal, also hints at this problem.

Engagement, then, is clearly most problematic when it looks to be potentially damaging to those to whom we feel a debt as part of our ethnographic experience. The Human Terrain System (HTS), not surprisingly, comes in for very severe criticism in this regard. The refining of the means of imperial violence through the enlightened application of "local knowledge" is almost perfectly calculated to offend ethnographic sensibilities. As a discipline, however, we have not used the example of HTS very principally. Is, for example, all "upward" collaboration with the powerful suspect? World Health Organization policies have been severely critiqued by anthropologists, such as Jim Kim. These policies have resulted at times in appalling levels of death and suffering. Similarly, many anthropological careers have been made in the World Bank, whose influence in many areas of the world has been at best checkered. Should collaboration with these organizations be viewed as more or less suspect than those few careers currently connected with the HTS? If not, why not?

Some scholars find their way out of these conundrums 
through the importation of a value system outside of anthropology per se. A good example cited by Low and Merry is Paul Farmer, who imports an explicit Catholic social activism/liberation theology admonition to "stand with the poor." If ethnography teaches us anything, though, it is how both poverty and power live in concrete social historical circumstances mostly as relative measures, and the world produces situations aplenty pitting relatively poor and powerless populations against one another, with victim and victimizer able to transform into one another with frightening rapidity. In this important collection, Low and Merry have provided a partial catalog of the diversity of the engagements of anthropology. Precisely because of its current positive valence, however, "engagement" itself needs to be critically interrogated. A necessary step in this process should be greater room to discuss those engagements in the history of the discipline and in the current moment, which will likely make anthropologists uncomfortable.

\section{María Teresa Sierra}

Centro de Investigaciones y Estudios Superiores en Antropologia Social, Calle Juárez 87, Colonia Tlalpan 14000, México DF, México (mtsierrac@hotmail.com).

Is it possible to carry out scientifically rigorous and politically committed research that uncovers the mechanisms of domination and contributes to social justice? Or should the production of anthropological knowledge defend a neutral scientific standpoint?

These questions continue to be central to anthropology in the twenty-first century, especially for those who argue for the need to reinforce the quest for the humanist ethos and search for social justice that has long characterized the discipline. At a time when neoliberal globalization has deepened structural inequalities across the world and contributed to polarization and violence in postcolonial societies and the socalled third world, anthropologists working in these contexts face the need to position themselves and make decisions about the direction and ethics of their research. Extreme cases of these dilemmas are those of anthropological collaborations in contexts of military occupation and those of activist research to support AIDS patients in South Africa. In some ways these two examples are poles apart and demand different responses in terms of a committed anthropology; for these reasons they cannot necessarily be judged according to the same standards. These are some of the concerns that run through the debate about committed anthropology in Setha M. Low and Sally Engle Merry's introduction to this special issue of Current Anthropology. Their essay revives one of the foundational debates of anthropology, namely, that concerning the ethics of anthropological research and a false dichotomy between scientific research and commitment.

Low and Merry reconstruct the genealogy of social and cultural anthropology in the United States by highlighting key moments, including the Boasian tradition against racism and fascism to the silences imposed by McCarthyism and anticommunism to the current moment, which appears to have given critical anthropology a renewed impulse. They argue that committed anthropology has many variants, including critical anthropology, activist anthropology, and advocacy. At the same time, they point to what they identify as some of the central dilemmas facing committed research, particularly those referring to ethics and neutrality and the risk of reproducing colonial positions, of taking sides and losing a critical perspective on power, and of providing firsthand knowledge to the military in an attempt to mitigate the negative effects of war. In their conclusions they underline the tensions and challenges facing committed anthropology today. In the following paragraphs I highlight some of the themes I consider central to the challenges of committed, politically positioned anthropology in Latin America and more generally in postcolonial societies.

1. The nature of research and its effect: what for and for whom? In Latin America the development of a critical anthropology linked to the struggle of indigenous peoples dates from the 1960s, as does the development of a social science committed to popular struggles, inspired by the contributions of dependency theorists and Latin American Marxists such as Orlando Fals Borda. These established the basis for an anthropology committed to social actors as indeed is the case today with activist research that supports the struggle of indigenous peoples for territory and autonomy. The questions of what research is for and whom it should serve have challenged the notion of "neutral" research. At the same time, to adopt an engaged position within a given field should not imply a noncritical view of all kinds of power relations.

2. The decolonization of anthropology and the search for alternative knowledge and epistemologies. The critique of the coloniality of power (colonialidad del poder; Anibal Quijano 2000 ), that is, the questioning of anthropological production and the applicability of theory derived from Western models to colonial and postcolonial societies, perhaps signals one of the major challenges facing anthropological practice today, particularly regarding the analysis of cultural diversity and of the state. Such positions have acquired new strength through the emergent role of indigenous intellectuals who defend alternative models of societies and who question the discursive colonialisms from which their realities have traditionally been analyzed and imagined. Such positions are clear, for example, in the production of the Nasa people in the Cauca region of Colombia. Current situated debates from different positions of gender, race, and class reveal the challenges of discussing essentialism and universalism from alternative frameworks of reference, something that in turn also affects the nature of anthropological research itself.

3. Challenges for a collaborative and dialogic anthropology. These recent developments generate new dilemmas and challenges for those who believe it is not possible to carry out neutral research in contexts of cultural diversity when power 
differentials are brought into relief and where actors take a stance vis-à-vis a range of different demands. Such contexts oblige us to deepen our dialogic strategies and our collaborative methods of research, taking into account the constitutive tensions and contradictions of these processes, as Charles Hale has rightly observed. Engaged collaborative practice that fights for social justice constitutes the ground for new theoretical insights gained through dialogue between actors that in turn contribute to these alternative forms of knowledge construction and cultural modeling.

Fortunately, committed anthropology appears to be gaining ground and legitimacy in a range of different national contexts, albeit remaining something of a countercurrent to prevailing orthodoxies. The essay by Setha Low and Sally Merry represents an important contribution in this respect.

\section{Merrill Singer}

Department of Anthropology, University of Connecticut, Storrs, Connecticut 06269, U.S.A. (merrill.singer@uconn .edu).

Discussion of engagement raises several issues, some of which cut to the core of anthropology as a scholarly tradition and as an applied field with social concerns and practical utility. Past debates about engagement have tended to revolve around questions of objectivity, responsibility, and partisanship. These were the focus of an academic exchange in Current Anthropology more than a decade ago. On one side, representing the pure science or positivist perspective, Roy D'Andrade dispassionately maintained that anthropologists must avoid all forms of moral bias and cleave to the objective path. The engagement of anthropologists, he argued, should be in the construction of falsifiable models of human behavior. Accordingly, he asserted, "Science works not because it produces unbiased accounts but because its accounts are objective enough to be proved or disproved no matter what anyone wants to be true" (D'Andrade 1995:404).

On the other side was Nancy Scheper-Hughes, who proposed a perspective that viewed knowledge as a means to a moral end. Asserting the subjectivist view that because all data are inherently biased by the social origins and structural positions of science and scientists, true objectivity, although socially useful in making claims for authority, is ultimately unattainable, rigorous scientific methodology notwithstanding. Consequently, she stated, anthropologists should engage in moral criticism and advocacy based on an "explicit ethical orientation to 'the [ethnographic] other"' (Scheper-Hughes 1995:418). Thus, she called for the development of "an active, politically committed, morally engaged anthropology" (Scheper-Hughes 1995:415). This orientation, keenly aware of the tarnished past of the discipline as well as its current moral ambiguity (Price 2008b; Rylko-Bauer, Singer, and van Willigen 2006; Singer 2008), is characterized by a belief in scholarly accountability in a sharply conflicted and decidedly inegalitarian world in which neutrality in the production of pure knowledge is a form of taking sides.

In their approach to this ongoing debate, Low and Merry seek "to broaden the range of what [is considered] engagement, showing how pervasive engagement is within anthropological scholarship." Rather than an outlier, they stress, engagement is deeply embedded in standard anthropological practice, including the basic commitments we make to our informants, the ways we find to support the communities where do our work, and our efforts to involve students directly in real-world research and applied initiatives. While Low and Merry are to be commended both for organizing the WennerGren workshop that led to this provocative set of articles and for their thoughtful overview of engaged anthropology, reading their introduction raises a number of questions. Is their net cast too broadly? In light of this wide-ranging review, can it be said that a distinct tradition of engagement exists in anthropology? If so, what distinguishes engagement as an approach to knowledge and application within the discipline? And, more specifically, if engagement and the commitments it implies are so central to our discipline, why are we, during an era purportedly informed by lessons of the U.S. war in Vietnam, now producing anthropologists who not only participate in programs such as the Human Terrain System (HTS) but defend it as objective, reasonable, and appropriate? As an embedded employee of the HTS in Iraq, certainly an anthropologist could gather data on perceived health care needs that are objective enough to be proved or disproved as accurate accounts of popular understandings. But doing so willfully ignores how U.S. military and economic power "have contributed to the degradation of the public health system and [the] health and well-being of Iraqis" (Harding and Libal 2010:78). In other words, in addition to the reasons the executive board of the AAA concluded that HTS involvement was a problematic application of anthropological expertise (e.g., inability to ensure informed consent, use of HTS information by the military to target individuals for military operations), from an engaged perspective such work contributes to the exercise of power in the cause of social injustice and social suffering.

While work of many kinds is of value, including all of the anthropological efforts cited by Low and Merry, the problem with an overly broad definition of engagement is that it obscures the most salient features of this orientation, and these are revealing, critiquing, and confronting the unjust use of power. As noted in the 1963 inaugural issue of the journal Transaction (now Society), those who embrace engaged anthropology believe that the social scientist studying contemporary problems and the complex relationships among modern peoples knows that he/she can no longer discharge his/ her social responsibilities by retreating into ivory-tower neutrality. As numerous studies, including in recent years, of the growing literatures on globalization, neoliberalism, global warming, health and social disparities, war and political violence, and AIDS make clear, human problems are urgent, 
divisions between social strata are growing, the contradictions of the global economy are multiple, and the social consequences that lie ahead are ominous.

\section{Claire Smith}

Department of Archaeology, Flinders University, GPO Box 2100, Adelaide 5001, South Australia, Australia (claire .smith@flinders.edu.au).

This introduction, and this special issue of Current Anthropology, identifies a pivot point in the development of anthropology in the United States concerning the public purpose of anthropology. We live in a world that has a myriad of words, and it is rare to read an article that truly makes a substantive difference. This is one such article. Its importance lies in pinpointing a moment of change and in identifying diverse trends and weaving them into a credible whole, making it possible to see the overall pattern as well as the constituent parts, and bringing conceptual clarity to a diverse and changing process.

In this commentary I consider the issues raised by Low and Merry primarily in terms of my own discipline of archeology. The archeology of engagement has developed in two broad directions: in critical reflection on conceptual and methodological issues and in case studies that are shaped by an active engagement with the communities with whom archaeologists intersect. Over the last two decades, archaeological engagement has been most active in the repatriation of human remains (Fforde, Hubert, and Turnbull 2002), the protection of indigenous cultural and intellectual property (Nicholas and Bannister 2004), the construction of identity (Ouzman 2005; Shepherd 2003), archaeological ethics (Zimmerman, Vitelli, and Hollowell-Zimmer 2003), and collaborative practice (Chilton 2009; Colwell-Chanthaphonh and Ferguson 2008).

Recently, discussions of archaeological ethics have segued into an active interest in human rights, structural violence, and social justice often as part of a more general concern with ethical globalization (e.g., Badran 2007; Bernbeck 2008; Smith 2007). In many parts of the world, people are more concerned with the challenges of day-to-day living than with caring for cultural heritage, and the archaeologists who work with these people are engaging with matters, such as social and cultural rights, that are beyond the traditional remit of the discipline. The critical change is a movement from archaeology plus engagement to archaeology as engagement. While the aims of the former are primarily archaeological, the aims of the latter are primarily social or political. The main aim of the award-winning Nelspoort project in central South Africa, for example, was to help street children gain desperately needed employment and self-worth (S. Ouzman, e-mail, March 22, 2010). Culture heritage was a means to this end, not the end in itself.

The challenges of today are very different to those of the past. One of the principal areas of concern for engaged archaeology is cultural heritage in zones of conflict. Today, wars are less about territory per se than they are about cultural dominance. As military interventions increasingly target cultural heritage as a proxy (see Bevan 2006), new challenges arise. Current debates concern not only the physical protection of cultural heritage but also the ethics of archaeological employment in the military and the complexities of ownership of cultural objects located in conflict zones.

Some new challenges arise from changing relationships. Low and Merry comment on the trend from people being the subjects of research to becoming collaborators, coresearchers, and colleagues. This is certainly true of archaeology, and this collaboration has engendered profound changes. Isaacson and Ford (2005), for example, call for archaeologists to commit to a shared future by engaging with the daily challenges that face the people with whom they work.

If archaeologists can bridge the barriers that traditionally separate private and professional lives, the future of the Indigenous community in which they work becomes a future in which they have a vested personal interest. If archaeologists see the Indigenous people with whom they work as more than just subjects of research, then archaeologists can no longer be silent observers to the problems Indigenous communities face every day. (Isaacson and Ford 2005:361-362)

Such deep community engagement is injecting new energy and ideas into archeology and changing aims, methods, and practice. Guided by a profound commitment to the needs and agendas of community peoples, this engaged archaeology is as liable to produce a press release or an opinion article in a newspaper as an academic paper or a consultancy report. It is generating archaeologists who consciously take on the role of social critic as they actively work to shape a better world for the people with whom they work and, through this, for themselves.

New methods bring new dilemmas. Archaeologists deeply engaged with communities may be called to act well beyond their disciplinary comfort zone. They may be asked to write the history of a community, develop funding applications or community management plans, or help people obtain medical care or access to education, all of which extends beyond their archaeological training. While the undertaking of such tasks provides much-needed assistance, it can raise questions around competence and purpose.

Finally, as archaeologies and anthropologies of engagement integrate a human rights framework into practice, pressing questions are raised. How can the communicative capacities of an interconnected world promote social justice or ethical globalization? Is a values-led globalization even possible? What changes are required of universities and other institutions to effectively address the ethical and moral challenges of a contemporary world (Robinson 2003)? This issue of Cur- 
rent Anthropology provides some answers and some new questions as it defines and precipitates an important turning point.

\section{Reply}

All the commentators stress the importance of our introduction and this collection in valorizing the role of engagement in contemporary anthropology. They also appreciate our emphasis on the multifaceted nature of engagement. Several commentators point out that both engagement and activism are complex concepts not easily unpacked or distinguished from closely related activities such as advocacy. They value our historical analysis that demonstrates that engagement is not new to anthropology but has been a concern running through the field since its founding. Claire Smith shows that there are close parallels to work presented from social and cultural anthropology in contemporary archaeology and historical preservation practice. María Teresa Sierra points out that an engaged anthropology committed to social justice and collaboration with indigenous peoples has been developed even further in Latin America than in the United States. On the other hand, she is also concerned with decolonizing the U.S. domination of anthropological knowledge that can take place only through greater collaboration and dialogue regardless of how "engaged" a project might be. We wonder whether a more global anthropology would address this problem because even a shift to a more engaged paradigm does not solve the North/South inequalities within the discipline. Nonetheless, in the collection of articles and the commentaries, there seems to be a growing consensus that anthropology should emphasize engagement and its links with past engaged and applied work.

Intriguingly, there is virtually no discussion in either the articles or the comments about the old distinction between the inherent conflicts of objectivity and ethical commitment in anthropological work. While other concerns were voiced, such as the tension between universal standards exemplified in human rights discourse and the support for cultural specificity that Kamran Ali discusses, there is little discussion of the necessity of a disengaged science that does not make value judgments or take a political or moral stance. This issue no longer seems relevant to these authors and commentators.

Instead, the commentators point out that engagement is about politics and power, an invaluable point that was not brought out as clearly as it should have been in our introduction. Several commentators point out that engagement is connected to ideas of social justice and does not simply refer to being embedded in a contradictory and complex social system. One can be engaged with the World Bank or with the U.S. military, for example, just as much as one is engaged with a community group facing eviction for urban renewal. Yet these two situations are politically quite different and align the anthropologist with different power regimes. Several commentators urge us to be more explicit about our politics as we become more involved in public and social issues. Catherine Lutz worries that even an engaged anthropology can lose its critical edge if practiced without attention to the webs of power in which the anthropologist is immersed. She cautions us to consider carefully what we are engaged in and who we are relating to, especially when working for the military, advertisers, and manufacturers. Merrill Singer advocates seeing engagement in terms of social justice and suggests that we are casting our net too widely. Instead, we should focus on improving the lot of the marginal and the poor as the hallmark and definition of engagement. While the forms of engagement might differ-from political activism as a citizen mentioned by James Peacock to anthropological critiques of social inequality-our commentators encourage us to take a stand.

As individuals and as citizens, however, we are strongly committed to ideas of social justice and to forms of anthropological scholarship that challenge forms of power that benefit some and harm or exclude others. But we also recognize that finding the politically and morally unambiguous space from which to make the claim that one is defending social justice is difficult. Things may change, so that the institution that looked like it was promoting social justice at one time turns out to be repressing it at another. The AAA executive board has condemned the Human Terrain System used in Afghanistan to gather anthropological data for the U.S. military, for example, but in the 1940s, many anthropologists worked to help the United States war effort. Do these two forms of anthropological aid to military activities differ because one was seen as a "bad" war and the other a "good" war? Does the former seem opposed to social justice and the latter to promote it? Yet virtually every war is justified to some extent by claims to promote social justice while its effects are widely destructive to the poor who fall in the way of the armed forces. Clearly, there are many challenges to identifying a fixed and specific space to stand from which social justice is readily recognized and understood.

Despite these difficulties, we agree that examining power relations is a critical dimension of engaged anthropology. There will never be a simple recipe for determining social justice and taking sides in engagement. Instead, the specificity of situations and the importance of a broad contextual analysis of power relations are as essential to an engaged anthropology as to all forms of anthropological research and writing. Only through such an examination can a politically informed engagement develop that is committed to social justice. Our understanding of engagement cannot be separated from social justice, despite the difficulties of being sure, in a variety of places and times, of knowing what that is.

Another criticism of our introduction commented on by Mark Goodale is our ambivalence in the way that we write about engagement and our position that engaged practice includes a wide array of practices. He seems to have been 
looking for a clear blueprint for what engagement should be and did not find it. But we cast a broad net and did not preach a "standard" form intentionally in that we wanted more anthropologists to be able identify their contribution within this rubric. This broad definition also opens us up to what David Price points out, that we might seem politically naive and that we did not adequately consider distinctions such as the delineation between engagement and nonengagement, where the decision not to be engaged could be the more politically activist rather than supporting the status quo. His critique is well taken, as is his warning that the term "activism" needs some unpacking, especially with regard to power, also discussed by other commentators. His conclusion is not whether anthropologists should be engaged, because "we are all engaging in some way or another," but with what political issues we engage with and whether they conform to the ethical standards of the discipline. We hoped to be more clear on this issue and will certainly address the boundaries and borderlands of engagement further in our future work. —Setha Low and Sally Engle Merry

\section{References Cited}

Ali, Kamran Asdar. 2010. Voicing difference: gender and civic engagement among Karachi's poor. Current Anthropology 51(suppl. 2):S313-S320.

Badran, Arwan. 2007. Equal access to international debate: visas and their implications. Archaeologies: Journal of the World Archaeological Congress 3(2):207-209. [CS]

Basch, Linda G., Lucie Wood Saunders, Jagna Wojcicka Sharff, and James Peacock. 1999. Transforming academia: challenges and opportunities for an engaged anthropology. Arlington, VA: American Anthropological Association.

Bennett, John W. 1996. Applied and action anthropology: ideological and conceptual aspects. Current Anthropology 37:23-53.

Bernbeck, Reinhard. 2008. Structural violence in archaeology. Archaeologies: Journal of the World Archaeological Congress 4(3): 390-413. [CS]

Berreman, Gerald D. 1968. Is anthropology alive? social responsibility in social anthropology. Current Anthropology 9(5):391-396.

Besteman, Catherine, and H. Gusterson, eds. 2005. Why America's top pundits are wrong: anthropologists talk back. Berkeley: University of California Press.

Bevan, Robert. 2006. The destruction of memory: architecture at war. London: Reaktion. [CS]

Biehl, João. 2005. Vita: life in a zone of social abandonment. Berkeley: University of California Press.

- 2007. Will to live: AIDS therapies and the politics of survival. Princeton, NJ: Princeton University Press.

Briggs, Charles. 2004. Theorizing modernity conspiratorially: science, scale, and the political economy of public discourse in explanations of a cholera epidemic. American Ethnologist 31(2):164-187.

Briggs, Charles, and Clara Mantini-Briggs. 2000. "Bad mothers" and the threat to civil society: race, cultural reasoning and the institutionalization of social inequality in a Venezuelan infanticide trial. Law and Social Inquiry 25:299-354.

Burawoy, Michael. 2005. For public sociology. American Sociological Review 70:4-28.

Caulfield, Mina Davis. 1969. Culture an imperialism: proposing a new dialectic. In Reinventing anthropology. Dell Hymes, ed. Pp. 182-212. New York: Random House.
Checker, Melissa. 2009. Anthropology in the public sphere, 2008: emerging trends and significant impacts. American Anthropologist 111:162-170.

Chilton, Elizabeth. 2009. Teaching heritage values through field schools: case studies from New England. In Heritage values in contemporary society. George Smith, Phyllis Messenger, and Hilary Soderland, eds. Pp. 147-158. Walnut Creek, CA: Left Coast. [CS] Chomsky, Noam, ed. 1997. The Cold War and the university: toward an intellectual history of the postwar years. New York: New Press.

Chrisman, Noel J. 2005. Community building for health. In Community building in the twenty-first century. Stan Hyland, ed. Pp. 167-191. Santa Fe, NM: School of American Research.

Clarke, Kamari M. 2009. Fictions of justice. Cambridge: Cambridge University Press.

- 2010. Toward a critically engaged ethnographic practice. Current Anthropology 51(suppl. 2):S301-S312.

Clifford, James, and George Marcus. 1986. Writing culture: the poetics and politics of ethnography. Berkeley: University of California Press.

Colwell-Chanthaphonh, Chip, and T. J. Ferguson. 2006a. Memory pieces and footprints: multivocality and the meanings of ancient times and ancestral places among the Zuni and Hopi. American Anthropologist 108(1):148-162.

. 2006b. Trust and archaeological practice: towards a framework of virtue ethics. In The ethics of archaeology: philosophical perspectives on archaeological practice. Chris Scarre and Geoffrey Scarre, eds. Pp. 115-130. New York, Cambridge University Press. —, eds. 2008. Collaboration in archaeological practice: engaging descendant communities. Lanham, MD: AltaMira.

Cowan, Jane, M. Dembour, and R. Wilson, eds. 2001. Culture and rights: anthropological perspectives. Cambridge: Cambridge University Press.

D’Andrade, Roy. 1995. Moral models in anthropology. Current Anthropology 36:399-408. [MS]

Das, Veena. 2007. Life and words: violence and the descent into the ordinary. Berkeley: University of California Press.

Das, Veena, A. Kleinman, M. Lock, M. Ramphele, and P. Reynolds. 2001. Remaking a world: violence, social suffering, and recovery. Berkeley: University of California Press.

Doughty, Paul. 1987. Vicos: success, rejection, and rediscovery of a classic program. In Applied anthropology in America. E. Eddy and W. Partridge, eds. Pp. 438-469. New York: Columbia University Press.

Eriksen, Thomas Hylland. 2006. Engaging anthropology: the case for a public presence. Oxford: Berg.

Farmer, Paul. 2003. Pathologies of power: health, human rights, and the new war on the poor. Berkeley: University of California Press. . 2004. An anthropology of structural violence. Current Anthropology 45:305-317.

. 2005. The banality of agency: bridging personal narrative and political economy. In Bringing the past into the present: family narratives of holocaust, exile, and diaspora. Barbara Rylko-Bauer, ed. Special issue, Anthropological Quarterly 78(1):125-135.

Ferguson, James. 1994. The anti-politics machine: “development," depoliticization, and bureaucratic power in Lesotho. Minneapolis: University of Minnesota Press.

. 2006. Global shadows: Africa in the neoliberal world order. Durham, NC: Duke University Press.

Ferguson, T. J., and Chip Colwell-Chanthaphonh. 2006. History is in the land: multivocal tribal traditions in Arizona's San Pedro Valley. Tucson: University of Arizona Press.

Fforde, Cressida, Jane Hubert, and Paul Turnbull. 2002. The dead and their possessions: repatriation in principle, policy, and practice. One World Archaeology 43. London: Routledge. [CS]

Fiske, Shirley J. 2009. Global change policymaking from inside the beltway: engaging anthropology. In Anthropology and climate change: 
from encounters to actions. Susan A. Crate and Mark Nuttall, eds. Pp. 277-291. Walnut Creek, CA: Left Coast.

Forman, Shepard. 1993. Diagnosing America: anthropology and public engagement. Ann Arbor: University of Michigan Press.

Fosher, Kerry B. 2009. Under construction: making homeland security at the local level. Chicago: University of Chicago Press.

Gal, Susan, and G. Kligman. 2000. The politics of gender after socialism. Princeton, NJ: Princeton University Press.

Geertz, Clifford. 1995. After the fact. Cambridge, MA: Harvard University Press. [DHP]

Gluckman, Max. 2002 (1958). "The bridge": analysis of a social situation in Zululand. In The anthropology of politics: a reader in ethnography, theory, and critique. J. Vincent, ed. P. 476. Malden, MA: Blackwell.

González, Norma. 2010. Advocacy anthropology and education: working through the binaries. Current Anthropology 51(suppl. 2): S249-S258.

González, Roberto J. 2004. Anthropologists in the public sphere: speaking out on war, peace, and American power. Austin: University of Texas Press.

- 2009. American counterinsurgency: human science and the human terrain. Chicago: Prickly Paradigm.

Goodale, Mark. 2006a. Introduction: anthropology and human rights in a new key. American Anthropologist 108:1-8.

. 2006b. Toward a critical anthropology of human rights. Current Anthropology 47:485-511.

- 2008. Dilemmas of modernity: Bolivian encounters with law and liberalism. Stanford, CA: Stanford University Press.

. 2009. Surrendering to utopia: an anthropology of human rights. Stanford, CA: Stanford University Press.

Gough, Kathleen. 1968. New proposals for anthropologists. Current Anthropology 9(5):403-435.

Gusterson, Hugh. 1996. Nuclear rites: a weapons laboratory at the end of the Cold War. Berkeley: University of California Press.

. 2004. People of the bomb: portraits of America's nuclear complex. Minneapolis: University of Minnesota Press.

Gusterson, Hugh, and Catherine Besteman, eds. 2010. The insecure American: how we got here and what we should do about it. Berkeley: University of California Press.

Hale, Charles. 2006. Activist research vs. cultural critique: indigenous land rights and the contradictions of politically engaged anthropology. Cultural Anthropology 21:96-120.

Harding, Scott, and Kathryn Libal. 2010. War and the public health disaster in Iraq. In The war machine and global health. Merrill Singer and G. Derrick Hodge, eds. Pp. 59-87. Lanham, MD: AltaMira. [MS]

Harris, Marvin, 1964. Patterns of race in the Americas. New York: Norton.

Herskovits, Meville J. 1928. The American Negro: a study in race crossing. New York: Knopf.

Herzfeld, Michael. 2010. Engagement, gentrification, and the neoliberal hijacking of history. Current Anthropology 51(suppl. 2): S259-S267.

Hill, Carole. 2000. Strategic issues for rebuilding a theory and practice synthesis. In The unity of the theory and practice in anthropology. Carole E. Hill and Marietta L. Baba, eds. Pp. 1-16. Washington, DC: American Anthropological Association.

Hinton, Alexander. 2002a. Annihilating difference: the anthropology of genocide. Berkeley: University of California Press.

. 2002b. Genocide: an anthropological reader. New York: Blackwell.

Hinton, Alexander, and R. Lifton. 2004. Why did they kill? Cambodia in the shadow of genocide. Berkeley: University of California Press.

Hinton, Alexander Laban, and Kevin Lewis O’Neill, eds. 2009. Genocide: truth, memory, and representation. Durham, NC: Duke University Press.
Howell, Signe. 2010. Norwegian academic anthropologists in public spaces. Current Anthropology 51(suppl. 2):S269-S277.

Huggins, Martha K., and Marie-Louise Glebbeek. 2009. Women fielding danger: negotiating ethnographic identities in field research. Lanham, MD: Rowman \& Littlefield.

Hymes, Dell, ed. 1969. Reinventing anthropology. New York: Random House.

Isaacson, Ken, and Stephanie Ford. 2005. Looking forward, looking back: shaping a shared future. In Indigenous archaeologies: decolonising theory and practice. Claire Smith and H. Martin Wobst, eds. Pp. 352-366. One World Archaeology 47. London: Routledge. [CS]

Jackson, John L., Jr. 2010. On ethnographic sincerity. Current Anthropology 51(suppl. 2):S279-S287.

Johnston, Barbara Rose. 2001a. Anthropology and environmental justice: analysts, advocates, mediators and troublemakers. In New directions in anthropology and the environment. Carole Crumley, ed. Pp. 132-149. Walnut Creek, CA: AltaMira.

. 2001b. Considering the power and potential of the anthropology of trouble. In Ecology and the sacred: engaging the anthropology of Roy A. Rappaport. Ellen Messer and Michael Lambeck, eds. P. 102. Ann Arbor: University of Michigan Press.

. 2006. Power, praxis and the social work of anthropology. Applied Anthropologist 26(2):97-105.

. 2010. Social responsibility and the anthropological citizen. Current Anthropology 51(suppl. 2):S235-S247.

Jones, Delmos. 1968. The multivillage community: village segmentation and coalescence in northern Thailand. Cross-Cultural Research 3:149-174.

Kemper, Robert V., and Anya Royce. 2002. Chronicling cultures: longterm field research in anthropology. Walnut Creek, CA: AltaMira.

Khagram, Sanjeev. 2002. Restructuring the global politics of development: the case of India's Narmada Valley Dams. In Restructuring world politics: transnational social movements, networks, and norms. S. Khagram, J. Riker, and K. Sikkink, eds. Pp. 206-231. Minneapolis: University of Minnesota Press.

Kirsch, Stuart. 2002. Anthropology and advocacy: a case study of the campaign against the Ok Tedi mine. Critique of Anthropology 22: 175-200.

Lamphere, Louise. 2004. The convergence of applied, practicing and pubic anthropology in the 21st century. Human Organization 63(4):431-443.

Lassiter, Luke Eric. 2005. Collaborative ethnography and public anthropology. Current Anthropology 46:83-106

Levitt, Peggy, and Sally Engle Merry. 2009. Vernacularization on the ground: local uses of global women's rights in Peru, China, India and the United States. Global Networks 9(4):441-461.

Low, Setha. 2002. Anthropological-ethnographic methods for the assessment of cultural values in heritage conservation. In Assessing the values of cultural heritage. M. de la Torre, ed. Pp. 31-50. Los Angeles: Getty Conservation Institute.

. 2003. Behind the gates: life, security and the pursuit of happiness in fortress America. New York: Routledge.

- 2004. Social sustainability: people, history, values. In Managing change: sustainable approaches to the conservation of the built environment. J. Teutonico, ed. Pp. 16-42. Los Angeles: Getty Conservation Institute.

- 2006. The erosion of public space and the public realm: paranoia, surveillance and privatization in New York City. City and Society 18(1):43-49.

2008. Social sustainability. In The heritage reader. G. J. Fairclough, R. Harrison, J. Jameson, and J. Schofield, eds. Pp. 392-404. New York: Routledge.

- 2010. Psychological, cultural and political theories of changing social relations in private housing schemes. Special interdis- 
ciplinary edition on sustaining communities. GeoJournal, doi: 10.1007/s10708-009-9334-1. Print publication forthcoming.

Low, Setha, Dana Taplin, and Suzanne Scheld. 2005. Rethinking urban parks: public space and cultural diversity. Austin: University of Texas Press.

Lutkehaus, Nancy C. 2008. Margaret Mead: the making of an American icon. Princeton, NJ: Princeton University Press.

Lutz, Catherine. 2001. Homefront: a military city and the American 20th century. Boston: Beacon.

- 2002. Making war at home in the United States: militarization and the current crisis. American Anthropologist 104:723-735.

- 2006. Empire is in the details. American Ethnologist 33: 593-611.

- ed. 2008. The bases of empire: the global struggle against U.S. military posts. London: Pluto.

Marcus, George E., and Michael M. J. Fischer. 1986. Anthropology as cultural critique. Chicago: University of Chicago Press.

Mattei, Ugo, and Laura Nader. 2008. Plunder: when the rule of law is illegal. Malden, MA: Blackwell.

Mead, Margaret. 1942. And keep your power dry: an anthropologist looks at America. New York: Morrow.

Merry, Sally Engle. 2001. Changing rights, changing culture. In Culture and rights: anthropological perspectives. J. Cowan, M. B. Dembour, and R. Wilson, eds. Pp. 31-56. London: Cambridge University Press.

2005. Anthropology and activism: researching human rights across porous boundaries. Political and Legal Anthropology Review 28:240-258.

. 2006. Human rights and gender violence. Chicago: University of Chicago Press.

- 2008. Gender violence: a cultural perspective. New York: Blackwell.

Mullings, Leith. 2005. Resistance and resilience: the Sojourner Syndrome and the social context of reproduction in central Harlem. Transforming Anthropology 13(2):79-91.

Mullings, Leith, Alaka Wali, Diane McLean, Janet Mitchell, Sabiyha Prince, Deborah Thomas, and Patricia Tovar. 2001. Qualitative methodologies and community participation in examining reproductive experiences: the Harlem Birth Right Project. Maternal and Child Health Journal 5(2):85-93.

Nader, Laura. 1972. Up the anthropologist: perspectives gained from studying up. In Reinventing anthropology. Dell Hymes, ed. Pp. 284-311. New York: Pantheon.

. 1997. The phantom factor: impact of the Cold War on anthropology. In The Cold War and the university: toward an intellectual history of the postwar years. Noam Chomsky, ed. Pp. 107-146. New York: New Press.

Nash, June C. 2007. Practicing ethnography in a globalizing world: an anthropological odyssey. Lanham, MD: AltaMira.

Nelson, Diane M. 2009. Reckoning: the ends of war in Guatemala. Durham, NC: Duke University Press.

Nicholas, George, and Kelly Bannister. 2004. Copyrighting the past? emerging intellectual property rights issues in archaeology. Current Anthropology 45(3):327-350. [CS]

Ouzman, Sven. 2005. Silencing and sharing southern African indigenous and embedded knowledge. In Indigenous archaeologies: decolonising theory and practice. Claire Smith and H. Martin Wobst, eds. Pp. 208-225. One World Archaeology 47. London: Routledge. [CS]

Patterson, Thomas. 2001. Toward a socially engaged, integrated, critical anthropology. Keynote address at James Young Colloquium, University of California, Riverside, February 27.

Peacock, James. 1997. The future of anthropology. American Anthropologist 99(1):9-29.

Pierpont, Claudia Roth. 2004. The measure of America. New Yorker, March 8.
Price, David. 2003. Subtle means and enticing carrots: the impact of funding on American Cold War anthropology. Critique of Anthropology 23(4):373-401. [DHP]

. 2004. Threatening anthropology: McCarthyism and the FBI's surveillance of activist anthropologists. Durham, NC: Duke University Press.

2007. Buying a piece of anthropology. 2. The CIA and our tortured past. Anthropology Today 23(5):17-22. [DHP]

2008a. Anthropological intelligence: the deployment and neglect of American anthropology in the Second World War. Durham, NC: Duke University Press.

- 2008b. Social science in harness: inside the Minerva Consortium. CounterPunch June 25, 2008. http://www .counterpunch.org/price06252008.html. [MS]

Quijano, Aníbal. 2000. Colonialidad del poder, Eurocentrismo y América Latina. Edgardo Lander, ed. Colonialidad del saber, Eurocentrismo y ciencias sociales. Pp. 201-246. Buenos Aires: CLACSO-UNESCO. [MTS]

Rappaport, Roy. 1993. Distinguished lecture in general anthropology: the anthropology of trouble. American Anthropologist 95:295-303.

Robinson, Mary. 2003. One human family: ethical globalisation in our times. First Michael Littleton memorial lecture, Dublin. http://www.realizingrights.org/index.php?option $=$ com_content \& task $=$ view\&id $=65 \&$ Itemid $=1($ accessed March 22, 2007). $[$ CS]

Roseberry, William. 2002. Political economy in the United States. In Culture/economy/power: anthropology as critique/anthropology as praxis. Winnie Lem and Belinda Leach, eds. Albany: State University of New York Press.

Rylko-Bauer, Barbara, Merrill Singer, and John van Willigen. 2006. Reclaiming applied anthropology: its past, present, and future. American Anthropologist 108(1):178-190.

Sanday, Peggy, ed. 1976. Anthropology and the public interest: fieldwork and theory. New York: Academic Press.

Sanford, Victoria. 2004. Buried secrets: truth and human rights in Guatemala. New York: Palgrave Macmillan.

Sanford, Victoria, and Asale Angel-Ajani. 2006. Engaged observer: anthropology, advocacy, and activism. New Brunswick, NJ: Rutgers University Press.

Sanjek, Roger. 2004. Going public: responsibility and strategies in the aftermath of ethnography. Human Organization 63(4): 444-456.

Schensul, Jean J., and Stephen L. Schensul. 1978. Advocacy and applied anthropology. In Social scientists as advocates: views from the applied disciplines. George Weber and George J. McCall, eds. Pp. 121-164. Beverly Hills, CA: Sage.

1992. Collaborative research: methods of inquiry for social change. In Handbook of qualitative research in education. Margaret D. LeCompte, Wendy L. Millroy, and Judith Preissle, eds. Pp. 161-200. San Diego, CA: Academic Press.

Scheper-Hughes, Nancy. 1992. Death without weeping: the violence of everyday life in Brazil. Berkeley: University of California Press.

. 1995. The primacy of the ethical: propositions for a militant anthropology. Current Anthropology 36:409-420.

Scheper-Hughes, Nancy, and Philippe Bourgois, eds. 2004. Violence in war and peace: an anthology. Malden, MA: Blackwell.

Shepherd, Nick. 2003. When the hand that holds the trowel is black ...; disciplinary self-representation and the issue of native labour in archaeology. Journal of Social Archaeology 3(3):334-352. [CS]

Silverman, Sydel. 2007. American anthropology in the middle decades: a view from Hollywood. American Anthropologist 109: 519-528.

Singer, Merrill. 1990. Another perspective on advocacy. Current Anthropology 31(5):548-549.

. 2000. Why I am not a public anthropologist. Anthropology Newsletter 11(2):12-13. 
2008. Applied anthropology. In A new history of anthropology. Henrika Kulick, ed. Pp. 326-340. Malden, MA: Blackwell. [MS]

Smart, Alan. 2010. Tactful criticism in Hong Kong: the colonial past and engaging with the present. Current Anthropology 51(suppl. 2): S321-S330.

Smith, Claire. 2007. Visa stories: human rights, structural violence and ethical globalisation. Archaeologies: Journal of the World Archaeological Congress 3(2):179-185. [CS]

Smith, Gavin. 1999. Confronting the present: towards a politically engaged anthropology. New York: Oxford University Press.

Speed, Shannon. 2006. At the crossroads of human rights and anthropology: toward a critically engaged activist research. American Anthropologist 108:66-76.

Spencer, Jonathan. 2010. The perils of engagement: a space for anthropology in the age of security? Current Anthropology 51(suppl. 2):S289-S299.

Starn, Orin. 1995. To revolt against the revolution: war and resistance in Peru's Andes. Cultural Anthropology 10:547-580.

Stull, Donald, and Jean J. Schensul. 1987. Collaborative research and social change: applied anthropology in action. Boulder, CO: Westview.

Susser, Ida. 2009. AIDS, sex, and culture: global politics and survival in southern Africa. New York: Blackwell.

. 2010. The anthropologist as social critic: working toward a more engaged anthropology. Current Anthropology 51(suppl. 2): S227-S233.

Sutton, Connie, ed. 1993. From Labrador to Samoa: the theory and practice of Eleanor Burke Leacock. Arlington, VA: American Anthropological Association for the Association of Feminist Anthropology, International Women's Anthropology Caucus.

Tate, Winifred. 2007. Counting the dead: the culture and politics of human rights activism in Colombia. Berkeley: University of California Press.

Textor, Robert. 2005. Margaret Mead: the world ahead: an anthropologist anticipates the future. New York: Berghahn.
Tsing, Anna. 2005. Friction: an ethnography of global connection. Princeton, NJ: Princeton University Press.

van Willigen, John. 2002. Applied anthropology: an introduction. 3rd edition. Westport, CT: Bergin \& Garvey.

Vincent, Joan. 1994. Anthropology and politics: visions, traditions, and trends. Tucson: University of Arizona Press.

Warren, Kay B. 2006. Perils and promises of engaged anthropology: historical transitions and ethnographic dilemmas. In Engaged observer: anthropology, advocacy and activism. Victoria Sanford and Asale Angel-Ajani, eds. Pp. 213-227. New Brunswick, NJ: Rutgers University Press.

Wax, Murray. 1978. Once and future Merlins: the applied anthropologists of Camelot. Human Organization 37:400-408.

Wax, Rosemary H. 1971. Doing fieldwork: warnings and advice. Chicago: University of Chicago Press.

Weidman, Dennis. 1976. The individual and innovation in the process of sociocultural adaptation to frontier situations. Papers in Anthropology 17:107-116.

Whiteford, Linda M. 2009. Approaches to policy and advocacy. In Social and behavioral foundations of public health. Jeannine Coreil, ed. Thousand Oaks, CA: Sage.

Whiteford, Linda M., and G. A. Tobin. 2007. Potable water as the key to survival and community recovery: disaster planning and practice. In Strategy and implementation of integrated risk management. S. Wang, G. Tang, J. Zhang, W. Song, J. Ammann, and C. Kux, eds. (with Graham Tobin). Pp. 227-453. Proceedings of the International Disaster Reduction Conference. Harbin, China: Quyan.

Wilson, Richard A. 2001. The politics of truth and reconciliation in South Africa: legitimizing the post-apartheid state. Cambridge: Cambridge University Press.

Wolf, Eric. 1969. Peasant wars of the twentieth century. New York: Harper \& Row.

Zimmerman, Larry J., Karen D. Vitelli, and Julie Hollowell-Zimmer, eds. 2003. A handbook for ethics in archaeology. Walnut Creek, CA: AltaMira. [CS] 